Discussion Paper Series A No.516

The Union Wage Premium, Voice, and Nonunion Workers' Attitudes: Before and After Japan's Lost Decade

Tsuyoshi Tsuru

April, 2009

Institute of Economic Research Hitotsubashi University

Kunitachi, Tokyo, 186-8603 Japan 


\title{
The Union Wage Premium, Voice, and Nonunion Workers' Attitudes: Before and After Japan's Lost Decade*
}

\author{
Tsuyoshi Tsuru \\ tsuru@ier.hit-u.ac.jp \\ Institute of Economic Research, Hitotsubashi University \\ Kunitachi, Tokyo 186-8603, Japan
}

\begin{abstract}
* This paper is the result of joint research with Takashi Yoshinaka (Cabinet Office), Hiroyuki Enoki (Ministry of Health, Labour and Welfare), and Hidenobu Tokuda (Cabinet Office). For the original version in Japanese, refer to Tsuru, Yoshinaka, Enoki and Tokuda (2009). For our analysis, we used microdata from a survey conducted for the 2007 Annual Report on the Japanese Economy and Public Finance. We also used microdata from the Japanese General Social Surveys (JGSS) obtained from the SSJ Data Archive of the Information Center for Social Science Research on Japan, Institute of Social Science, University of Tokyo. Mr. Masayoshi Matsumoto (M.A. graduate of the Graduate School of Economics, Hitotsubashi University) provided assistance in the data compilation as well as useful advice on the program writing for our estimation. Moreover, we received valuable comments from participants of the Hitotsubashi University Workshop on Industrial Organization and Labor (July 8, 2008), especially Hiroyuki Chuma, Toshie Ikenaga, Daiji Kawaguchi, Ryo Kambayashi, and Hiroyuki Odagiri. The author of this paper and his collaborators would like to express their gratitude to the above-mentioned institutions and researchers for the assistance and suggestions provided. Thanks are also due to Tomohiko Noda, who was the discussant of an earlier version of this paper at a seminar at the Institute of Economic Research of Hitotsubashi University (December 17, 2008) and to Jun Saito and Fumihira Nishizaki at the Cabinet Office for comments received during the preparation of the discussion paper. Finally, the usual disclaimer applies: the analysis and opinions presented in this paper are the personal view of the author and should in no way be ascribed to the Cabinet Office or the Ministry of Health, Labour and Welfare of the Japanese government.
\end{abstract}




\begin{abstract}
Using microdata derived from the same questionnaire surveys conducted in 1992 and 2007, this paper examines changes in the economic effects of labor unions and attitudes toward unionization among nonunion workers in Japan. The main findings are as follows. First, while no union wage effects were observed in 1992, a wage premium for male workers was found in 2007. However, no change was observed for female workers. Second, with regard to union voice effects, no such effect was evident in 1992, but in 2007, a decline among men in the propensity for voluntary quitting (and, to some extent, job satisfaction) was found. In contrast, among women, no such union voice effects could be detected. Third, among male nonunion workers, support for unionization had increased between 1992 and 2007. On the other hand, the increase in support for unionization among female nonunion workers was scant when compared with that for their male counterparts. Furthermore, if there were other, nonunion forms of representing employees' voice at the workplace, this largely substituted for female support for unionization. (J31, J32, J51)
\end{abstract}




\section{Introduction}

In their now classic book What Do Unions Do?, Freedman and Medoff (1984) open their discussion of the topic as follows (p.3): "Trade unions are the principal institution of workers in modern capitalistic societies. For over 200 years, since the days of Adam Smith, economists and other social scientists, labor unionists, and businessmen and women have debated the social effects of unionism. Despite the long debate, however, no agreed-upon answer has emerged to the question: What do unions do?” In the remainder of the book, the authors provide a coherent answer to this question and, as a result, What Do Unions Do? has become firmly established as a cornerstone for the economic analysis of labor unions. However, since the first publication of the book, developments have emerged that are inconsistent with Freeman and Medoff's predictions regarding the effectiveness of unions. One such development, for example, is the precipitous decline in union density in many countries around the world; another is the growing importance of, and interest in, alternative forms of employee representation other than labor unions.

In Japan, too, the work of Freeman and Medoff has sparked an interest in the role of labor unions and a host of empirical studies followed in its wake. In this context, a key point of interest in Japan has been the effect of unions on wages. However, the findings of these studies remained largely inconclusive. Studies conducted at the beginning of the 1990s arrived at contradictory results regarding union wage effects, and it is only in the new millennium that general support for a positive effect of unions on wages was found. Rephrasing the original question posed by Freeman and Medoff, one could therefore ask: "What did unions do in the 1990s, and what do unions do today?”

Against this background, and focusing on Japan, this paper pursues the following three objectives. First, it seeks to examine why the conflicting conclusions with regard to union wage effects in the 1990s and 2000s emerged and whether the different results reflect changes in union behavior during this period. The second objective is to investigate changes in union voice effects, which are another major issue addressed by Freeman and Medoff (1984). Finally, the third objective is to examine changes in attitudes among nonunion workers with regard to unionization at their workplace. To analyze these three issues, two unique datasets are used: the results of a survey of individual workers conducted by the Japan Institute of Labor (now the Japan Institute for Labour Policy and Training) in 1992; and the results of a repeat survey using the same questionnaire implemented by the Cabinet Office in 2007.

The remainder of the paper is organized as follows. Section 2 provides an overview 
of preceding research on the economic effects of labor unions and outlines the research agenda. Section 3 presents a description of the data used for analysis. Section 4 begins the empirical analysis, focusing on union wage effects, while Section 5 concentrates on union voice effects. Section 6 then looks at nonunion workers' attitudes toward unionization. A discussion of the result obtained is provided in Section 7, and Section 8 concludes.

\section{The Economic Effects of Unions: Previous Research and Research Agenda}

\subsection{Previous Research}

\section{Union wage effects ${ }^{1}$}

The purpose here is to provide only a brief look at principal studies relevant to the analysis in the remainder of the paper. Table 1 presents an overview of major studies on union wage effects and their results. Three patterns stand out. First, studies using data for the 1980s find a significant negative wage effect. Second, studies using data compiled at the beginning of the 1990s find virtually no evidence of a union wage premium. And third, studies based on survey data for the 2000s, arrive at a significant positive wage premium.

Two possible interpretations can be drawn from these results. One is that, as Blanchflower and Bryson (2007) found for the United States, the wage premium moves countercyclically, that is, it is large during economic downturns and small during economic upswings. However, whether this is also the case for Japan is difficult to determine because there is hardly any research on wage premiums in Japan for the latter half of the 1990s. The other possible interpretation is that the prolonged recession of the 1990s (the "Lost Decade") brought about changes in the union wage effect in Japan that are quite unrelated to the question of whether changes in wage premiums are countercyclical or not. Using data for before and after the Lost Decade, the analysis below suggests that this is indeed the case.

\section{Union voice effects ${ }^{2}$}

\footnotetext{
1 The term "wage effect" here refers to the wage differential between workers belonging to a labor union and workers not belonging to a labor union (including workers employed at firms where there is no labor union). The wage differential is also referred to as the "union wage premium."

2 The term "voice effect" here refers to differences between workers belonging to a labor union and
} 
The effects of unions are of course not limited to wages. Since Freeman and Medoff (1984), a large number of studies have provided evidence that unions can change the channels of communication between labor and management. Above all, unions can raise the bargaining power of workers with regard to a variety of workplace-related issues. In the United States, this union voice effect has often been used to explain low job separation rates. By helping to resolve workplace-related problems and thus providing an alternative to quitting ("exit"), unions decrease the likelihood that a worker will leave a company.

One way to examine whether workers value the bargaining power provided by unions is to quantitatively examine the extent to which union membership affects job separation. If, in addition to resolving workplace-related problems, union voice provides an effective alternative to quitting, one should observe that, holding other factors fixed, the propensity for job separation among unionized workers is lower than that among nonunion workers. However, the propensity for job separation is only an indirect indicator of the value workers place on their current job. A more direct method therefore is to examine the effect that union membership has on workers' degree of job satisfaction.

Studies examining the effect of labor unions on voluntary job separation or the intention to change jobs in Japan include Muramatsu (1984), Tomita (1993), and Tsuru and Rebitzer (1995). Whereas Muramatsu (1984) and Tomita (1993) found that union membership had the effect of reducing voluntary job separations, Tsuru and Rebitzer's (1995) result suggested that unions do not significantly reduce exit propensities.

In this context, a recent study of great interest is the one by Todate (2007). Using data by industry from the Survey of Employment Trends for the years 1984 to 2002, Todate examined the impact of unionization rates on voluntary and firm-initiated separations. He found that for men a higher unionization rate significantly lowered the rate of voluntary separation and that although the estimated coefficient for women had the same sign, it was not statistically significant. Todate provided two reasons to explain the different results for men and women. The first is that, with the exception of grievance procedures, unions' policies tend to center on men. The second is that women tend to be less integrated into firms than men and their job tenure tends to be

workers not belonging to a labor union (including workers employed at firms where there is no labor union) in terms of job separation rates and job dissatisfaction. Job separation rates and the degree of job dissatisfaction are assumed to be linked to whether matters improve when workers voice dissatisfaction regarding working conditions or management issues. 
shorter, so that women cannot capture the long-term benefits of union membership. The advantages of union membership and voice are therefore small.

\section{Nonunion workers' support for unionization ${ }^{3}$}

Research on nonunion workers' attitudes toward unionization in Japan is rather scant. However, one notable study in this field is the one by Noda and Tachibanaki (1993). Using data from a survey they conducted among firm employees, they implemented a probit analysis where the dependent variable was whether workers thought a union was necessary in their firm. They found that workers who thought that a union was necessary tended, for example, to expect that this would bring an improvement in wages and better access to information regarding the firm's management, and such workers also tended to be dissatisfied with personnel evaluation. However, Noda and Tachibanaki also found that certain groups of workers whose shares in overall employment had increased, such as women and white collar workers, only attached a relatively low value to labor unions. Finally, they found that, against this background, merit systems based on individual performance were making inroads and a growing number of workers were seeking to improve their lives by raising their performance at work rather than trying to improve working conditions through joining a union, while the number of workers wanting to organize a union at nonunion firms decreased. This last point provides the main reason for the decline in unionization rates in Japan.

The study by Noda and Tachibanaki focuses on nonunion workers' attitudes as an important factor explaining unionization rates. In particular the quantitative analysis, following the example of Farber (1990) for the United States, of how attitudes toward unionization among nonunion workers are related to dissatisfaction and worker attributes represents an important step, and their argument that the encroachment of the merit system has led to the disappearance of workers willing to take charge of organizing a union provides a novel explanation.

The most important recent research on attitudes toward unionization among nonunion workers is two studies by Hara and Sato (2004, 2005). Using data from a questionnaire survey on private firm employees residing in the Tokyo area, the Kansai (i.e., Kyoto and Osaka) region, and the twelve major cities of Japan, they search for the sources of union support. It is well known that dissatisfaction with working

\footnotetext{
3 "Nonunion workers' support for unionization" refers to the view among workers at firms with no union that "it would be better to establish a union at the firm."
} 
conditions is a major factor underlying support for unionization (Tsuru and Rebitzer, 1995). However, in addition to this, Hara and Sato found the following. First, support for unionization is affected by the extent of workers' understanding of workers' rights (such as basic workers' rights and various worker protection laws). Second, support for unionization is positively correlated with the perception of labor unions' effectiveness. And third, support for unionization is lower among workers in nonunion firms than among workers in union firms.

While Hara and Sato found that support for unionization at nonunion firms is low, why this is the case remains an issue that has not yet been examined in detail. A possible reason is that in many nonunion firms in Japan, other, nonunion arrangements - such as labor-management consultations, employee organizations, etc. - are in place (Tsuru, 2002; Tsuru and Morishima, 1999), and an intriguing research issue therefore is what effect the existence of such alternative arrangements has on the support for unionization among nonunion workers.

\subsection{Research Agenda}

Given the above considerations, this paper analyzes the economic effects of unions from the following three angles. The first is the union wage effect. Specifically, in addition to the union effect on wage levels by estimating wage functions, the effect of unions on wage distributions is examined by employing counterfactual kernel density estimates following the methodology of DiNardo, Fortin and Lemieux (1996). ${ }^{4}$ Second, the union voice effect is examined. Using a probit model, the union effect on the propensity for voluntary quitting and the degree of job dissatisfaction is estimated. And third, the determinants of support for unionization are examined. Specifically, again using a probit model, this part of the analysis looks at the relationship between support for unionization (i.e., the formation of a union) by nonunion workers on the one hand and, on the other, various variables representing worker attributes and alternative voice mechanisms such as labor-management consultation arrangements and employee associations.

\section{The Data}

\footnotetext{
4 The first to apply this method to Japanese data were Hara and Kawaguchi (2008).
} 
The analysis in this paper uses cross-section data for two different years based on the same questionnaire. The first set of cross-section data is from a survey conducted by the Japan Institute of Labor (now the Japan Institute for Labour Policy and Training) in 1992. The sample frame consists of 2,800 men and women aged 18 to 59, residing within a radius of $30 \mathrm{~km}$ from Tokyo Station (i.e., in Tokyo, Kanagawa, Chiba, and Saitama) and drawn through stratified two-stage random sampling from the Basic Resident Register. Among the 2,800 men and women, 1,736 were in employment, and these were chosen as the survey subjects. 1,104 replied to the survey, for a response rate of 63.6 percent. For the survey, respondents were interviewed at their residence and the entire survey was conducted between February 7 and 24, 1992.

The second set of cross-section data is from a survey conducted by the Cabinet Office in 2007. This is a repeat survey using the same questionnaire as in 1992. The sample frame consists of 5,000 men and women residing in the Tokyo metropolitan area (Tokyo, Kanagawa, Chiba, and Saitama) and randomly chosen from among the mail survey monitor registrants of Intage, Inc., a market research company in Japan. Among these, 4,371 responded to the survey for a response rate of 87.4 percent. The entire survey was conducted by mail and took place between February 16 and 26, 2007.

Table 2 provides a comparison of the population and the sample in each of the two years. As can be seen, the survey respondents represent a cross-section that quite accurately reflects workers in the Tokyo metropolitan area. The ratio of labor union members in the samples is 32.1 percent in 1992 and 29.2 percent in 2007. These values are higher than the estimated national unionization rates of 24.4 percent (1992) and 18.1 percent (for 2007), which, however, likely reflects that estimated unionization rates for the Tokyo metropolitan area are also several percentage points higher than the national average. ${ }^{5}$

The survey is confined to workers in the private sector. Summary statistics for each of the variables after outliers were removed from the sample are shown in Table 3. Note that the 1992 survey did not ask about the existence of labor-management consultation mechanisms.

\footnotetext{
${ }^{5}$ Using the Ministry of Health, Labour and Welfare's Basic Survey on Labor Unions as well as the Ministry of Internal Affairs and Communications' Labor Force Survey and Establishment and Enterprise Census to calculate unionization rates for 2007 by region, the estimate for greater Tokyo (Tokyo, Kanagawa, Chiba and Saitama) is 20.9 percent and that for Tokyo 24.7 percent.
} 


\section{Union Wage Effects}

This section begins the empirical analysis by measuring the effect of union membership on wage levels (total annual salaries). The results are displayed in Table 4 and indicate that in the 1992 data, no wage premium was measured either for men or for women. In contrast, in the data for 2007, again no wage premium was observed for women, but a positive wage premium of around 9 percent was measured for men. ${ }^{6}$ This result remains almost unchanged if the sample is limited to full-time regular employees, i.e., excluding part-time workers (not shown in the table). ${ }^{7}$

In order to explore the underlying reasons for the differences between 1992 and 2007, the following two graphical comparisons using counterfactual kernel density estimates based on the approach of DiNardo, Fortin and Lemieux (1996) are conducted. ${ }^{8}$ The first comparison takes workers with the attributes of union members

${ }^{6}$ A further notable difference between 1992 and 2007 is that the coefficient on the years of employment for women decreased by about one-third. To explore the reason for this, the estimation was repeated dividing the observations for women into full-time regular and part-time workers. The results indicate that whereas the coefficient for full-time women remained basically unchanged between the two years, that for part-time women declined. In other words, the decrease in the coefficient on the years of tenure for women overall is the result of the increased share of part-time workers rather than a decrease in the years of employment of full-time women. With regard to men, the coefficient on the years of employment remained almost unchanged, but the coefficient on the years of employment squared declined. This can be interpreted as indicating that the role of seniority in determining wages is dominant but diminishing over the life cycle for male employees.

7 The reason for estimating separate wage functions for men and women is that, in terms of the labor market overall, the structure of wage determination differs for men and women. Of course, within a particular firm, the structure of wage determination for men and women, for instance in terms of ability-based grade systems, is likely to be identical. Moreover, labor unions are likely to conduct wage negotiations without distinguishing between men and women. However, the sample used in the analysis here contains many workers employed in small and medium-sized businesses, and there is little reason to assume that in the sample overall, the wage structure for men and women is the same.

${ }^{8}$ The underlying idea of counterfactual kernel density estimates is the following. In order to examine whether a particular attribute (such as union membership) accounts for differences in the distribution of wages of those with and those without that attribute in two different periods, a counterfactual kernel density estimate compares the actual wage distribution for those with the attribute of interest (e.g., union membership) at one time and the counterfactual wage distribution for those without the attribute of interest after controlling for other attributes (educational attainment, years of employment, etc.) at another time. This means that, taking into account that workers' wages are determined by the wage 
in 1992 and 2007 and compares the (actual) wage distribution of those that were union members and the (counterfactual) wage distribution of those that were not union members (Figures 1 and 2). The second comparison focuses on workers' status in 2007 and compares the (actual) wage distribution in 2007 with the (counterfactual) wage distribution in 1992 (Figures 3 and 4).

Beginning with Figure 1, it can be seen that the (counterfactual) wage distribution of male union members in 1992 had they worked in the nonunion group is not to the left of the actual wage distribution, that is, union members' wages would not have been lower had they not been union members. In fact, the "bump" to the right suggests that for a certain group, wages would have been higher than they actually were. However, for 2007, the (counterfactual) wage distribution for male union members had they worked in the nonunion group lies to the left of the actual distribution. Put differently, the wage distribution of the union group is at a relatively higher position than that of the nonunion group.

Figure 2 presents the results for women. In contrast with the men's case, the (counterfactual) wage distribution for female union members had they belonged to the nonunion group leans to the left of the actual wage distribution, indicating a positive union wage effect. However, the (counterfactual) wage distribution in 2007 for female union members had they belonged to the nonunion group is more concentrated than the actual distribution and compared with 1992, there is a much greater overlap.

Next, focusing on workers' union membership status in 2007, the (actual) wage distribution for 2007 and the (counterfactual) wage distribution for workers with the same attributes had they worked in 1992 are examined (Figure 3 and 4). Beginning with the group of male unionized workers, it can be seen that the actual distribution for 2007 lies to the right of the counterfactual distribution for 1992. On the other hand, for the group of nonunion workers, the two distributions essentially overlap. For the case of women, the actual distribution in 2007 lies to the right of the counterfactual distribution for 1992 irrespective of union membership status. ${ }^{9}$

structure of the sector in which they work as well as their individual attributes, a counterfactual distribution is estimated in which only workers' individual attributes are controlled for. For a more detailed explanation, refer to appendix 2 of Kawaguchi and Hara (2007).

9 Figures 3 and 4 can be interpreted as implying that the composition of workers is held fixed while the wage schedule was changed. To check these results, the analysis was repeated holding the wage schedule fixed while allowing the composition of workers to change. Similar to the results shown in Figures 3 and 4, the only large change was observed for the group of unionized men. What these results 
Returning now to the significant positive wage premium for men observed in 2007, the above analysis suggests this is the result of (a) the fact that in 2007 the wage distribution for union members was to the right of that (i.e., wages were higher than) for nonunion members; and (b) while the wage distribution for nonunion workers in 2007 was almost unchanged from that in 1992, it has shifted to the right (implying higher wages) for union workers. On the other hand, for women, the wage distribution shifted toward the right (implying higher wages) irrespective of whether they were union members or not.

While the analysis so far has provided a comparison between 1992 and 2007, it is also of great interest to explore what happened in the intervening years. Therefore, to gain a snapshot of the period between 1992 and 2007, the same analysis is conducted using data from the Japanese General Social Surveys (JGSS) covering the period from 2000-2005. ${ }^{10}$

Figure 5 shows the actual wage distributions for male union and nonunion workers in 2005 and compares these with the estimated counterfactual distributions for workers with the same attributes in 2000. In the case of male union workers, it can be seen that the distribution for 2005 lies to the right (implying higher wages) of the counterfactual distribution for 2000. This is essentially the same result as that suggested in Figure 3. On the other hand, no right-ward shift in the wage distribution for male nonunion workers can be observed.

Moreover, as can be seen in Figure 6, the wage distribution for female union members for 2005 has a relatively large "bump" to the right (implying high wages), especially when compared with the counterfactual distribution for 2000 for the same female union members. A similar pattern, though less pronounced, can be observed for female nonunion workers. While the result for female union members differs from that shown in Figure 4, that for female nonunion workers is essentially the same.

The above results indicate that while male union members enjoyed an increase in wages between 2000 and 2005, male nonunion workers did not experience such an increase. In contrast, among women, nonunion workers experienced an improvement in wages that was close to that seen for female union members. The patterns regarding changes between 2000 and 2005 largely correspond to those seen in the comparison of 1992 and 2007. Overall, the results for men provide concrete evidence that during the

suggest is that the composition of workers changed more in union firms than in nonunion firms.

10 It should be noted that no survey was conducted in 2004. 
Lost Decade a positive union wage effect emerged in Japan. ${ }^{11}$

\section{Union Voice Effects}

In order to examine union voice effects, as a first step, the extent to which labor unions provide voice is examined. Table 5 shows that in the data for 1992, the share of workers replying that "Even if there are problems at my workplace, I don't tell anybody about my grievances” is lower among union members than nonmembers, thus indicating that labor unions do offer a voice channel. This pattern, where the share of those saying they do not tell anyone about their grievances is lower among union than nonunion workers, remains basically unchanged in 2007, implying that unions continue to represent a voice channel for workers. ${ }^{12}$

As a second step, the effect of union membership on the propensity for voluntary quitting and the degree of workplace dissatisfaction in 1992 and 2007 is examined. ${ }^{13}$

11 To obtain further confirmation, using microdata from the Ministry of Health, Labour and Welfare's Survey on Wage Increases (1991 to 2007), changes in average wages were regressed on whether a firm has a union or not, on firm size, and on industry. The coefficient on the union dummy was positive and significant at the 1 percent level for the years 1993-1999, 2001, and 2005, indicating that a positive union wage effect can also be ascertained when focusing on wage revisions by firms, thus providing confirmation of the wage increases for union workers from the early 1990s to the 2000s shown in the analysis above.

12 A notable pattern is that, with the exception of harassment, the ratio of nonunion workers not voicing dissatisfaction is higher than that of union workers. Especially with regard to wage levels and welfare benefits, almost half of nonunion workers say that they do not voice any grievances.

13 Labor unions not only provide workers with a collective voice, but, through the part they play in maintaining job security, also have a restraining effect on job separation rates. In addition, job separation rates tend to be low at firms with a labor union also because such firms have typically traditionally adhered to long-term employment practices. However, it should be noted that while unions' collective voice helps to lower quits initiated by employees themselves since it helps to resolve workers' grievances, this differs from employment protection and long-term employment practices, which reduce separations initiated by firms (i.e., restructuring). In this paper, the union voice effect is examined by focusing on voluntary job quitting, which is used as the dependent variable, while variables related to long-term employment, such as firm size or workers' years of employment are used as independent variables, so that long-term employment as a factors is controlled for. 
Table 6 shows the results, which indicate the following.

First, in 1992, both for men and women, union membership did not have any measurable effect either in terms of the propensity for voluntary quitting or the degree of job dissatisfaction. Second, in 2007, union membership did significantly lower the propensity for voluntary job quitting for men (and although the result is not significant at the 10 percent level, the coefficient with regard to the degree of job dissatisfaction now has the correct sign and the $p$-value is 0.111 ). However, for women still no such union effect can be observed in 2007. In sum, whereas no union voice effect was found in 1992, for men such an effect did operate in 2007. This pattern is in line with the results above, i.e., that a union wage premium was observed only for men in 2007.

\section{Attitudes Toward Unionization Among Nonunion Workers}

The preceding sections suggested that it was indeed possible to observe economic effects of labor unions. This being so, one would expect that this at least partly provides an incentive for nonunion workers to form a labor union at their workplace. But what are nonunion workers' attitudes to unionization in practice?

As can be seen in Table 7, in 1992, the percentage of nonunion workers supporting unionization was less than half among both men (43.3 percent) and women (37.8 percent). However, in 2007, a majority of men (55.7 percent) supported unionization. On the other hand, among women the rate was still only 43.1 percent and thus clearly lower than that among men (the difference between men and women is statistically significant at 1 percent level).

Given this background, the purpose here is to explore the sources of support for unionization among nonunion workers. This is done by regressing support for unionization on factors that are likely to influence unionization support. Included as explanatory variables here are not only workers' attributes and their dissatisfaction with working conditions, but also variables relating to voice mechanisms such as the presence of joint labor-management consultation mechanisms and employee associations. The results are presented in Table 8. Beginning with those for 1992, they indicate that among men, dissatisfaction with wages had a positive effect on the support for unionization; on the other hand, women were more likely to support unions the larger their firm was and the more they were dissatisfied with welfare benefits.

Looking now at the results of the same estimation for 2007, prominent changes that

stand out are that for men, the dummy for recreation-oriented employee associations is 
positive and significant. If there is such an organization, this pushes up the support for unionization by more than 10 percentage points. On the other hand, the dummies for the presence of a joint consultation system and for a voice-oriented employee association are not significant. However, in the estimation for women, the coefficient on the voice-oriented employee association dummy is significantly negative. If there is a voice-oriented employee association, this pushes down the support rate for unionization by 40 percentage points. These results suggest that for men, recreation-oriented employee organizations play a complimentary role to unionization, while for women, voice-oriented employee organizations tend to serve as a substitute for unionization. This phenomenon that the presence or absence of worker organizations influences attitudes toward unionization was not seen in 1992.

\section{Discussion}

The main findings can be summarized as follows. First, whereas no union wage effects were observed in 1992, a wage premium for male workers had emerged in 2007. However, no such premium could be observed for female workers. Second, and similarly, no union voice effect was found for 1992, but in 2007, union membership reduced the propensity for job quitting (and, possibly, the degree of job dissatisfaction) among men. However, for women, no such voice effect could be confirmed. And third, perhaps as a result of these trends, the support for unionization among male nonunion workers seems to have increased. On the other hand, the increase in support for unionization among nonunion women was small when compared with men, and if there exists a voice-oriented employee association at the workplace, this largely substitutes for support for unionization among women. The following subsections provide an interpretation of the results.

\section{Union wage effects}

To start with, the fact that a union wage effect was found for men but not for women is likely to have something to do with the behavior of both labor unions and firms. Two different interpretations are possible.

The first interpretation is to regard the union wage effect as a demonstration of the bargaining power of labor unions. Amid the prolonged economic stagnation from 1992 to 2007, nonunion firms implemented almost no wage increases and the wage distribution for men at such firms remained unchanged. Any wage increases won by labor unions in the wage negotiation during the traditional "spring offensive" did not 
spill over to nonunion firms. ${ }^{14}$ As a result, wages in union firms increased relative to those in nonunion firms.

On the other hand, with regard to women, a series of legal measures were introduced to improve their situation at the workplace, beginning with the implementation of the Equal Employment Opportunity Law in April 1986 and followed by additional measures during the 1990s and 2000s, such as the Childcare Leave Law implemented in April 1992, the ban on discrimination in the Revised Equal Employment Opportunity Law implemented in April 1999, and the Revised Child and Family Care Leave Law implemented in April 2002. ${ }^{15}$ As can be seen in Figure 7, when focusing on standard workers (i.e., workers that directly entered a firm after graduating from school and then worked for the firm continuously, and excluding non-regular workers such as temporary workers), the wage differential between men and women appears to have shrunk during this period. Given this background, a possible scenario is that as a result of the legal provisions the working conditions in both union and nonunion firms have improved and that the wages of both unionized and nonunionized women have moved in a similar fashion. ${ }^{16}$

The second interpretation is that the union wage premium was brought about unintentionally through the introduction of measures by firms to deal with the prolonged economic stagnation in Japan. Hara (2003), for example, using a firm survey conducted in 2003, found that although more union firms than nonunion firms had implemented restructuring measures, including personnel reductions, few of them cut wages. This finding is also confirmed by the results of our analysis using microdata of the Ministry of Health, Labour and Welfare's Survey on Wage Increases (for 1991 to 2007). As is shown in Figure 8, when asked which measures firms considered the most pressing with regard to keeping personnel expenses in check, the

\footnotetext{
14 Cabinet Office (2007) reports that the proportion of firms that cited "going wages" as an important factor when revising basic wages was substantially lower in the early 2000s than in the 1990s, irrespective of whether firms were unionized or not. In addition, the gap in the timing of revising wages by firms with union and those without unions shrunk in the 1990s. Based on this evidence, it is possible to argue that wage spillovers from union to non-union firms became weak in the 1990s and the early 2000s.

15 The principle of equal wages for men and women in the Labor Standards Law only banned discrimination with regard to wages. However, the Revised Equal Opportunity Law also bans discrimination with regard to job assignments and promotions and it is expected that this will help to correct the qualitative wage differentials between men and women arising from discriminatory treatment with regard to assignments and promotions.

16 This line of reasoning is one that has not been mentioned in the literature so far and may provide a new vantage point from which to analyze wage effects among women.
} 
percentage of firms citing "personnel retrenchment and natural attrition” as the most important measure was higher among union than among nonunion firms. At the same time, as reported in Table 9, the percentage of firms that implemented regular pay raises was also higher among unionized firms. Taken together, the pattern that these findings suggest is that union firms tended to keep their labor costs in check by curbing new hires, which then made it possible to maintain or even raise wage levels. On the other hand, nonunion firms, even if they were already restraining labor costs through personnel adjustments, additionally also tended to adjust wages downward.

There is no direct evidence supporting this latter interpretation. However, regressing changes in annual income on a firm size dummy, with large firms of 1,000 or more employees, for which unionization rates tend to be comparatively high, as the reference group, Kuroda and Yamamoto (2006) find that the coefficients for firms with fewer than 1,000 employees are all significantly negative. This result is consistent with the interpretation that firms' restructuring measures play a role in the appearance of the union wage effect.

\section{Union voice effect}

The next issue to address is why a union voice effect was observed for men in 2007 when none was found for 1992. A likely explanation, which is similar to the one for the union wage effect, is that unions, on the one hand, accepted restructuring measures such as workforce reductions, but on the other strove to protect the working conditions, such as wages, of existing workers. ${ }^{17}$

But this leaves unanswered the question why no union voice effect was observed for women. To gain some traction on this issue, it is necessary to start by looking at changes in the way workers voiced grievances at the workplace and whether they did so through individual channels ("I talk to management by myself" or "I talk to my superior”) or through collective voice channels (“I talk to the labor union”). Overall, both in 1992 and 2007, the most common reply given as to which route is chosen to voice grievances is "I talk to my superior," followed by "I talk to the labor union."

\footnotetext{
${ }^{17}$ In terms of the proportion of those wishing to change jobs, that among male union members increased only by 2.2 percentage points from 1992 to 2007, while that among male nonunion workers increased substantially by 19.0 percentage points. For women, the corresponding figures were increases of 9.0 percentage points for union members and 8.8 percentage points for nonunion workers.
} 
Although for brevity no table is provided here, when examining the effect of union membership on the choice of individual or collective voice channels, the following pattern emerges. Compared with 1992, there was a larger number of items where the share of both men and women replying "I talk to the labor union" increased than decreased. ${ }^{18}$ On the other hand, while there was a large number of items where the share of male union members replying "I communicate with management through my superior" increased than decreased, the opposite was the case for female union members.

However, the above results do not yet provide conclusive evidence of union voice, since it is possible that the observed greater exercise of collective voice has come at the expense of the exercise of individual voice. To take this possibility into consideration, it is useful to look at whether being a union member has the effect of opening up channels for expressing dissatisfaction. ${ }^{19}$ The results indicate that for men, union membership provided channels for expressing dissatisfaction with regard to a much larger number of items in 2007 than in 1992. On the other hand, for women, union membership opened up channels for expressing dissatisfaction for only some of the items. This suggests that although initiatives by labor unions mean that women

${ }^{18}$ As for items on which job dissatisfaction might focus, the surveys provided the following seven categories: (1) wages; (2) working hours, holidays, vacation leave; (3) welfare benefits; (4) employment stability; (5) assessment and setting of salaries and bonuses; (6) staff rotation (including transfer policies); and (7) harassment. As for how workers voiced any dissatisfaction with regard to these items, the surveys provided respondents with the following options: (1) I talk to management by myself; (2) I talk to management together with my co-workers; (3) I communicate with management through my superior; (4) I communicate with management through the employee association or recreational association; (5) I communicate with management through the joint consultation system; (6) I talk to the labor union; (7) I talk to administrative bodies such as the labor administration office; (8) I talk to external organizations, such as telephone advice services for part-time workers; and (9) I don't talk to anybody. Looking at the share of union workers saying "I talk to the labor union," this increased from 1992 to 2007 among men for five items and among women for four items. On the other hand, the share of union workers saying "I communicate with management through my superior" declined both among men (for three items) and women (for five items).

${ }^{19}$ This is examined by conducting a probit analysis using a dummy variable for "I don't talk to anyone” (taking a value of 1 if applicable, 0 otherwise) as the dependent variable. Doing so, the coefficient on the dummy variable for union membership was significantly negative in the estimation for 1992 for men in the case of zero items and for women in the case of two items, while in the estimation for 2007 it was significantly negative for men in the case of seven items and for women in the case of four items. 
now have a stronger collective voice than in the past to address women's working conditions, these initiatives have been insufficient to provide women with as many channels to express dissatisfaction as men.

\section{Nonunion workers' support for unionization}

Finally, the analysis also highlighted differences between male and female workers in terms of the support for unionization among nonunion workers. The most likely explanation for this, as shown by the estimation results obtained by Hara and Sato (2004, 2005), is that nonunion workers clearly perceive the different union wage and voice effects for men and women, and this leads to differences between men and women in their attitude toward unionization. However, it is possible that nonunion workers are not that clearly aware of the benefits of unionization. An alternative, though less rigorous interpretation may therefore be more appropriate. For example, against the background of deregulation and weakening employment protection since the early 1990s, it could be argued that men, in their role as main or sole providers of household income, have become more sensitive to the issue of employment protection and, as a consequence, are more inclined to the notion that "labor unions can protect employment” than women.

It seems rather difficult to explain why recreation-oriented employee associations raise the support for unionization among men, while voice-oriented employee associations lower women's support for unionization. According to the empirical analysis in Tsuru (2002), recreation-oriented employee associations and voice-oriented employee associations have in common that they express employees' concerns with regard to welfare benefits; however, they differ in that recreation-oriented associations express workers' concerns with regard to working hours, holidays, and vacation leave, while voice-oriented associations express workers' concerns with regard to annual management plans and production schedules. In other words, some of the latter may be not dissimilar to labor unions in that they provide voice on aspects such as working conditions and management issues. Moreover, compared with recreation-oriented ones, voice-oriented employee associations also tend to function in a more firmly established manner. Overall, therefore, men may tend to see voice-oriented organizations as an imperfect substitute for labor unions, while women consider it as a sufficient substitute.

Applying the same logic to recreation-oriented employee associations, these provide only a loose type of organization at a firm. And this, in turn, may lead men, who feel under greater pressure to support the household, to prefer an institutionalized union. In 
other words, it is possible that, as a result of declining job stability due to the loosening of employment protection laws, there are moves toward turning simple, recreation-oriented employees associations into unions. In fact, this interpretation is backed up by the fact that, according to a survey conducted at the end of June 2007, there has been an increase in the number of labor union members for the first time in 13 years, i.e., since 1994, while another survey carried out at the end of June 2008 showed that the unionization rate, which had been declining for a long time, stopped falling for the first time in 27 years, i.e., since 1981, and moved sideways. ${ }^{20}$ These results suggest that, along with the change in the employment environment, there are also signs of changes in attitudes towards labor unions.

\section{Conclusion}

What do unions do in Japan? This is the question posed at the outset of this paper, and the analysis presented here has provided the following answers.

First, whereas no union wage effect was observed in 1992, a wage premium for men could be observed in 2007. However, for women, no such wage premium was found. With regard to union voice effects, again no such effect was evident in 1992, but in 2007, a decline among men in the propensity for voluntary quitting (and, to some extent, the degree of job dissatisfaction) was found. In contrast, among women, no such union voice effects could be detected. Third, among male nonunion workers, support for unionization increased between 1992 and 2007. On the other hand, the increase in support for unionization among female nonunion workers was scant when compared with that for their male counterparts. Furthermore, if there exists a voice-oriented employee association at the workplace, this largely substituted for female support for unionization.

These results have various implications for labor relations in Japan. First, the fact that a union wage effect was observed indicates that labor unions exercised their bargaining power in wage negotiations and in particular were able to win regular annual pay rises. On the other hand, the phenomenon that these wage improvements did not spread to nonunion firms suggests that the "spring offensive"is no longer fulfilling its previous role and has become an empty shell. Second, it is notable that the positive union wage effect has been accompanies by personnel reductions at unionized companies. In other words, unions have been able to maintain wage levels, but only in exchange for adjustments in employment. Third, it appears that unions do not

${ }^{20}$ Ministry of Health, Labour and Welfare, Basic Survey on Labor Unions $(2007,2008)$. 
sufficiently understand the grievances and requirements of female workers. For this reason, unions tend to fail to resolve the workplace grievances of women, and, moreover, were unable to reduce voluntary job quitting. The impression of labor unions that emerges from this is that they focus their resources on guarding the interests of male union members in the firm. The results of this, in terms of the economic effects of unions, were shown above. However, at the same time, this narrow focus also limits the social significance of labor unions in Japan. 


\section{References}

Blanchflower, David G. and Bryson, Alex (2007) "What Effect Do Unions Have on Wages Now and Would Freeman and Medoff Be Surprised?," in James T. Bennett and Bruce E. Kaufman (eds.) What Do Unions Do? A Twenty-Year Perspective, New Brunswick New Jersey: Transaction Publishers, pp.79-113.

Brunello, Giorgio (1992) "The Effect of Unions on Firm Performance in Japanese Manufacturing,” Industrial and Labor Relations Review, Vol.45, No.3, pp.471-487.

Cabinet Office (2007), "Rodo Shijo no Henka to Kakei Bumon he no Eikyo [Labor Market Change and Its Impact on the Household Sector]," Heisei-19-nendo nenji keizai zaisei hokoku [2007 Annual Report on the Japanese Economy and Public Finance], ch.3, pp.171-245.

DiNardo, John, Fortin, Nicole and Lemieux, Thomas (1996) “Labor Market Institutions and the Distribution of Wages, 1973-1992: A Semiparametric Approach,” Econometrica, Vol.64, No.5, pp.1001-1044.

Farber, Henry S. (1990) "The Decline of Unionization in the United States: What Can Be Learned from Recent Experience?” Journal of Labor Economics, Vol.8, No.1, pp.S75-105.

Freeman, Richard B. and Medoff, James L. (1984) What Do Unions Do?, New York: Basic Books, Inc.

Hara, Hiromi (2003) "Kumiai ha Nanno Tame Ni? Fukyo Taisaku to Chingin wo Megutte [What Are Unions For? - Issues Surrounding Anti-Recession Measures and Wages]," in Research Institute for Advancement of Living Standards, Rodo Kumiai ni kan suru Ishiki Chosa Hokokusho [Report on the Survey on Attitudes Toward Labor Unions], Part 2, ch.3, pp.118-134.

Hara, Hiromi and Kawaguchi, Daiji (2008) “The Union Wage Effect in Japan,” Industrial Relations, Vol.47, No.4, pp.569-590.

Hara, Hiromi and Sato, Hiroki (2004) "Rodo Kumiai Shiji ni Nani ga Eikyo wo Ataeru ka? - Rodosha no Kenri ni kan suru Rikai ni Chakumoku shite [What Affects Labor Union Support? Focusing on an Understanding of Workers' Rights,” Nippon 
Rodo Kenkyu Zasshi [Japanese Journal of Labor Studies], No.532, pp.54-70.

Hara, Hiromi and Sato Hiroki (2005) "Kumiai Shiji to Kenri Rikai [Union Support and the Understanding of Rights," in Keisuke Nakamura and Research Institute for Advancement of Living Standards (eds.), Suitai ka Saisei ka? - Rodo kumiai kasseika he no michi [Decline or Revival? -- The Way Forward to Reinvigorate the Labor Union], ch.2, Tokyo: Keiso Shobo, pp. 71-84.

Kalleberg, Arne L. and Lincoln, James R. (1988) "The Structure of Earnings Inequality in the United States and Japan," American Journal of Sociology, Vol.8, Supplement, pp.S121-S153.

Kawaguchi, Daiji and Hara, Hiromi (2007) "Nihon no Rodo Kumiai ha Yaku ni Tatte iru no ka? [Are Japan’s Labor Unions Useful?],” JILPT Discussion Paper 07-2, The Japan Institute for Labor Policy and Training.

Kuroda, Sachiko and Yamamoto, Isamu (2006) Defure ka no Chingin Hendo: Meimoku Chingin no Kaho Kochokusei to Kinyu Seisaku [Wage Fluctuation Under Deflation: Nominal Wage Downward Rigidity and Financial Policy], Tokyo: University of Tokyo Press.

Muramatsu, Kuramitsu (1984) "Rishoku Kodo to Rodo Kumiai: Taishutsu, Hatsugen Apurochi [Job Separation Behavior and Labor Unions: An Analysis Based on a Quits and Voice Approach], in Kazuo Koike (ed.), Gendai no Shitsugyo [Contemporary Unemployment], Tokyo: Dobunkan.

Nitta, Michio and Shinozaki, Takehisa (2008) "Rodo Kumiai no Chingin Koka no Kensho [An Analysis of the Wage Effect of Labor Unions,” in Ichiro Tanioka, Michio Nitta and Noriko Iwai (eds.), Nihonjin no Ishiki to Kodo - Nihonban Sogoteki Shakai Chosa JGSS ni yoru Bunseki [The Attitudes and Behavior of the Japanese: An Analysis Based on the Japanese General Social Surveys (JGSS)], ch.6, Tokyo: Tokyo University Press, pp.121-133.

Noda, Tomihiko (2005) "Rodo Kumiai no Koka - Chingin to Koyo Chosei ni tai suru Koka no Kento [The Effectiveness of Unions: An Investigation of the Effects on Wages and Employment Adjustments]," in Keisuke Nakamura and Research Institute for Advancement of Living Standards (eds.), Suitai ka Saisei ka - Rodo Kumiai Kasseika he no Michi [Decline or Revival: The Way Forward to Reinvigorate Labor Unions], ch.2, Tokyo: Keiso Shobo, pp. 71-84. 
Noda, Tomihiko and Tachibanaki, Toshiaki (1993) "Misoshiki Rodosha to Noryoku Shugi [Nonunion Workers and the Merit System," in Toshiaki Tachibanaki and Research Institute for Advancement of Living Standards (eds.), Rodo Kumiai no Keizaigaku Kitai to Genjitsu [The Economics of Labor Unions: Economic Expectations and Reality], ch.4, Tokyo: Toyo Keizai Shinposha, pp. 69-88.

Tachibanaki, Toshiaki, and Noda, Tomohiko (1993) “Chingin, Rodo Joken to Kumiai [Wages, Working Conditions and Labor Unions],” in Toshiaki Tachibanaki and Research Institute for Advancement of Living Standards (eds.), Rodo Kumiai no Keizaigaku Kitai to Genjitsu [The Economics of Labor Unions: Economic Expectations and Reality], ch.10, Tokyo: Toyo Keizai Shinposha, pp. 195-216.

Todate, Mitsunori (2007) "Rodo Kumiai to Rishokuritsu [Labor Unions and Separation Rates],” Nippon Rodo Kenkyu Zasshi [Japanese Journal of Labor Studies], No.568, pp.51-62.

Tomita, Yasunobu (1993) "Rishokuritsu to Rodo Kumiai no Hatsugen Koka [Job Separation Rates and Union Voice Effects],” in Toshiaki Tachibanaki and Research Institute for Advancement of Living Standards (eds.), Rodo Kumiai no Keizaigaku Kitoku to Genjitsu [The Economics of Labor Unions: Economic Expectations and Reality], ch.9, Tokyo: Toyo Keizai Shinposha, pp. 173-193.

Tsuru, Tsuyoshi (2002) Roshi Kankei no Nonyunion-ka - Mikuroteki, seidoteki bunseki [The Nonunionization of Labor Relations: A Micro and Institutional Analysis], Tokyo: Toyo Keizai Shinposha.

Tsuru, Tsuyoshi and Rebitzer, James (1995) "The Limits of Enterprise Unionism: Prospects for Continuing Union Decline in Japan,” British Journal of Industrial Relations, Vol.33, No.3, pp.459-492.

Tsuru, Tsuyoshi, and Morishima, Motohiro (1999) "Nonunion Employee Representation in Japan,” Journal of Labor Research, Vol.20, No.1, pp.93-110.

Tsuru, Tsuyoshi, Yoshinaka, Takashi, Enoki, Hiroyuki, and Tokuda, Hidenobu (2009) "Rodo Kumiai No Chingin Hatsugen Koka to Misoshiki Rodosha no Soshikika Shiji Ushinawareta 10 Nen no Zengo Hikaku [Union Wage and Voice Effects and Nonunion Workers' Attitude Toward Unionization: Before and After Japan's Lost Decade,” Economic Review, Hitotsubashi University, forthcoming. 
Table 1. Major preceding studies on union wage effects

\begin{tabular}{|c|c|c|c|c|}
\hline Author(s) and year of publication & Survey period & Data source and sample size & Union wage effect & Comment \\
\hline $\begin{array}{c}\text { Before the Lost Decade } \\
\text { Kalleberg and Lincoln (1988) }\end{array}$ & $1981-83$ & $\begin{array}{l}\text { Questionnaire survey of 3,735 } \\
\text { employees at } 46 \text { plants in Kanagawa } \\
\text { prefecture. }\end{array}$ & $\begin{array}{l}\text { Men: }-13.2 \% \text { (statistically significant) } \\
\text { Women: }-15.4 \% \text { (statistically significant) }\end{array}$ & \\
\hline Brunello (1992) & 1987 & $\begin{array}{l}979 \text { union and nonunion manufacturing } \\
\text { firms from the Yearbook of Japanese } \\
\text { Unlisted Companies. }\end{array}$ & $-2.8 \%$ (statistically significant) & \\
\hline Tachibanaki and Noda (1993) & 1991 & $\begin{array}{l}\text { Questionnaire survey of } 689 \text { firms } \\
\text { nationwide. }\end{array}$ & Not statistically significant. & \\
\hline Tsuru and Rebitzer (1995) & 1992 & $\begin{array}{l}\text { Questionnaire survey of 1,104 workers } \\
\text { in the greater Tokyo area. }\end{array}$ & Not statistically significant. & \\
\hline $\begin{array}{l}\text { After the Lost Decade } \\
\text { Noda (2005) }\end{array}$ & 2003 & $\begin{array}{l}\text { Questionnaire survey of } 391 \text { survey } \\
\text { monitor registrants in greater Tokyo, } \\
\text { Kansai region, and twelve major cities. }\end{array}$ & $\begin{array}{l}\text { Men: }+11.3 \% \text { (statistically significant) } \\
\text { Women: }-5.3 \% \text { (not statistically } \\
\text { significant) }\end{array}$ & \\
\hline Hara and Kawaguchi (2008) & 2000-03 & $\begin{array}{l}\text { Sample of 2,415 persons from the } \\
\text { Japanese General Social Surveys } \\
\text { (JGSS). }\end{array}$ & $\begin{array}{l}\text { Men and women overall: }+17 \% \\
\text { (statistically significant) }\end{array}$ & $\begin{array}{l}\text { After controlling for industry and } \\
\text { occupation: }+7 \% \text { (statistically } \\
\text { significant); also provides factor } \\
\text { decomposition following DiNardo, } \\
\text { Fortin and Lemieux (1996). }\end{array}$ \\
\hline Nitta and Shinozaki (2008) & 2000-03 & $\begin{array}{l}\text { Sample of } 1,432 \text { persons working at } \\
\text { firms with } 30 \text { or more employees from } \\
\text { the Japanese General Social Surveys } \\
\text { (JGSS). }\end{array}$ & $\begin{array}{l}\text { Men and women overall: }+12.6 \% \\
\text { (statistically significant) } \\
\text { Men: }+5.1 \% \text { (statistically significant) } \\
\text { Women: }+24.1 \% \text { (statistically } \\
\text { significant) }\end{array}$ & Working hours are not controlled for. \\
\hline
\end{tabular}


Table 2. Comparison of samples and population

1992

(a) Sample structure by sex and union membership

\begin{tabular}{l|c|c}
\hline & Number of persons & Sample share (\%) \\
\hline Men & 654 & 59.2 \\
Women & 450 & 40.8 \\
Union members & 354 & 32.1 \\
\hline
\end{tabular}

(b) Age distribution of sample and population

\begin{tabular}{|c|c|c|c|c|c|c|}
\hline Age in years & $18-19$ & $20-29$ & $30-39$ & $40-49$ & 50-59 & Total \\
\hline \multicolumn{7}{|l|}{ Sample } \\
\hline Men & 3.2 & 27.7 & 32.3 & 21.9 & 15.0 & 100 \\
\hline Women & 2.7 & 29.8 & 22.0 & 29.1 & 16.4 & 100 \\
\hline Total & 3.0 & 28.5 & 28.1 & 24.8 & 15.6 & 100 \\
\hline \multicolumn{7}{|l|}{$\begin{array}{l}\text { Population } \\
\text { nation }\end{array}$} \\
\hline$\overline{\text { Men }}$ & 5.9 & 28.7 & 21.7 & 24.7 & 19.0 & 100 \\
\hline Women & 5.9 & 26.4 & 21.3 & 26.2 & 20.3 & 100 \\
\hline Total & 5.9 & 27.6 & 21.5 & 25.4 & 19.7 & 100 \\
\hline
\end{tabular}

(Note) The population consists of 18 to 59-year-olds within a $30 \mathrm{~km}$ radius of Tokyo Station. The population data are taken from Management and Coordination Agency (1990), Population Census of Japan .

\section{7}

(a) Sample structure by sex and union membership

\begin{tabular}{l|c|c}
\hline & Number of persons & Sample share (\%) \\
\hline Men & 2544 & 58.2 \\
Women & 1827 & 41.8 \\
Union members & 1146 & 29.2 \\
\hline
\end{tabular}

(b) Age distribution of sample and population

\begin{tabular}{l|c|c|c|c|c|c}
\hline Age in years & $18-19$ & $20-29$ & $30-39$ & $40-49$ & $50-59$ & Total \\
\hline \multicolumn{7}{l}{ Sample } \\
\hline Men & 0.7 & 20.5 & 34.4 & 23.1 & 21.2 & 100 \\
Women & 0.3 & 22.6 & 29.5 & 22.4 & 25.3 & 100 \\
Total & 0.5 & 21.4 & 32.2 & 22.8 & 23.0 & 100 \\
\hline Population & 1.7 & 21.6 & 28.9 & 23.4 & 24.3 & 100 \\
Men & 2.2 & 24.8 & 25.2 & 24.1 & 23.8 & 100 \\
Women & 1.9 & 23.0 & 27.2 & 23.7 & 24.1 & 100 \\
Total &
\end{tabular}

(Note) The population consists of 18 to 59-olds residing in the Tokyo metropolitan area (Tokyo, Kanagawa, Chiba, and Saitama) among the 240,000 mail survey monitor registrants of Intage, Inc. 
Table 3. Summary statistics

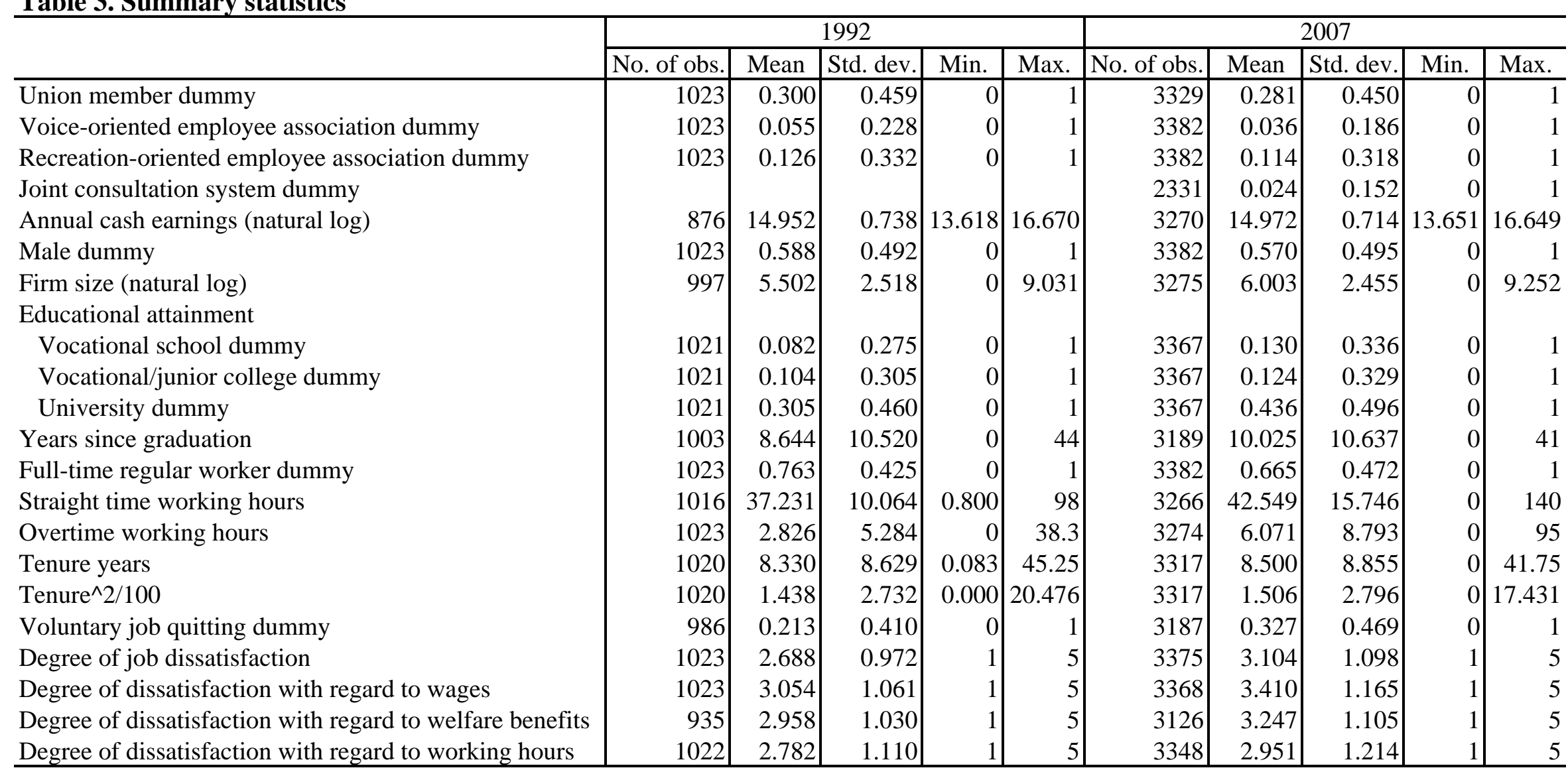




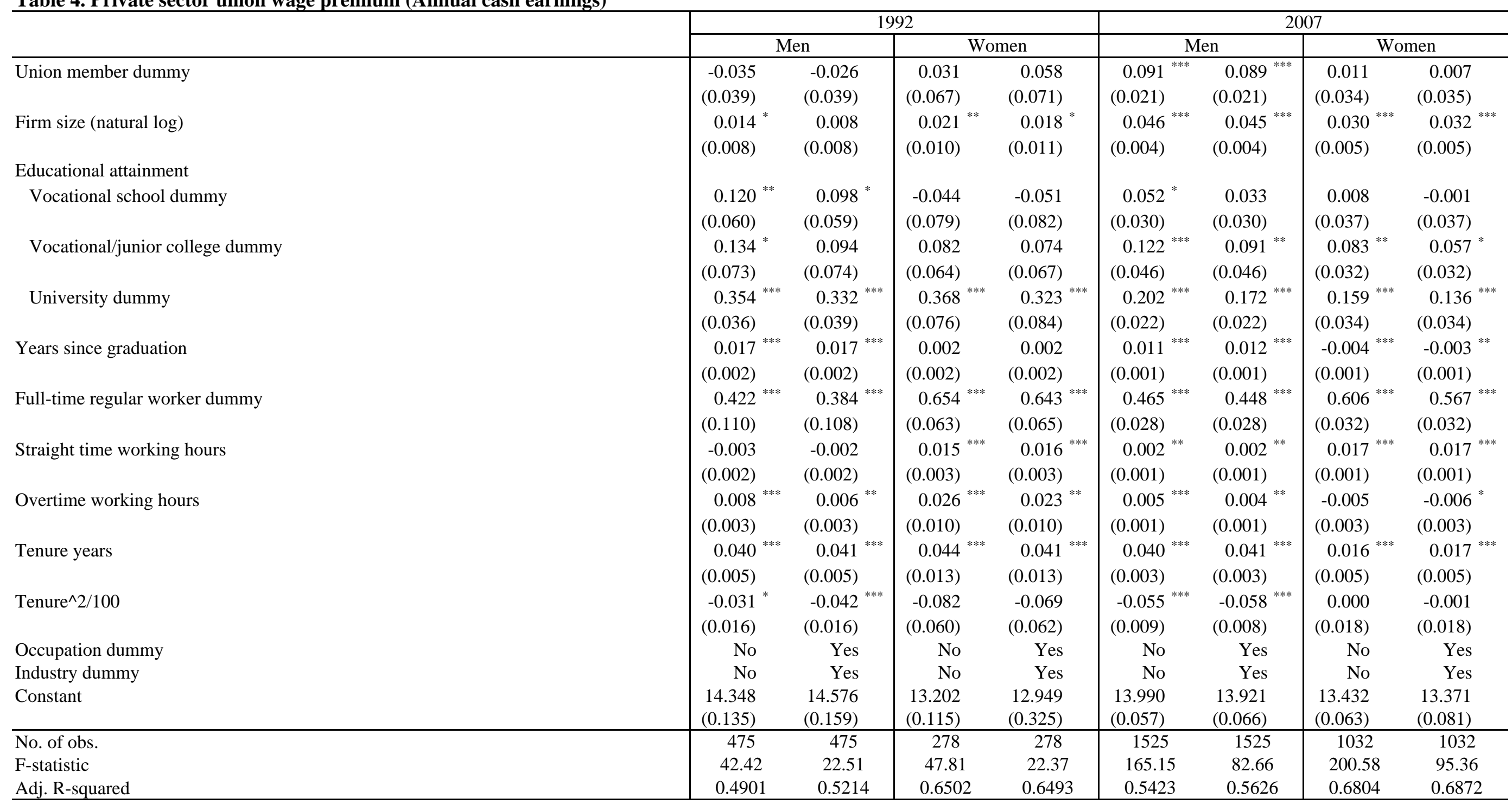

(Notes) $^{\text {a }}$ Estimated using ordinary least squares. The dependent variable is the log of annual cash earnings. Standard errors are given in parentheses.

${ }^{* * *},{ }^{* *}$ and ${ }^{*}$ indicate statistical significance at the $1 \%, 5 \%$, and $10 \%$ level, respectively.

${ }^{\mathrm{b}}$ Because the dependent variable is the natural log of annual cash earnings in the preceding year, tenure is estimated only for those with one or more years of tenure. 


\section{Figure 1. Counterfactual kernel density, male regular workers}
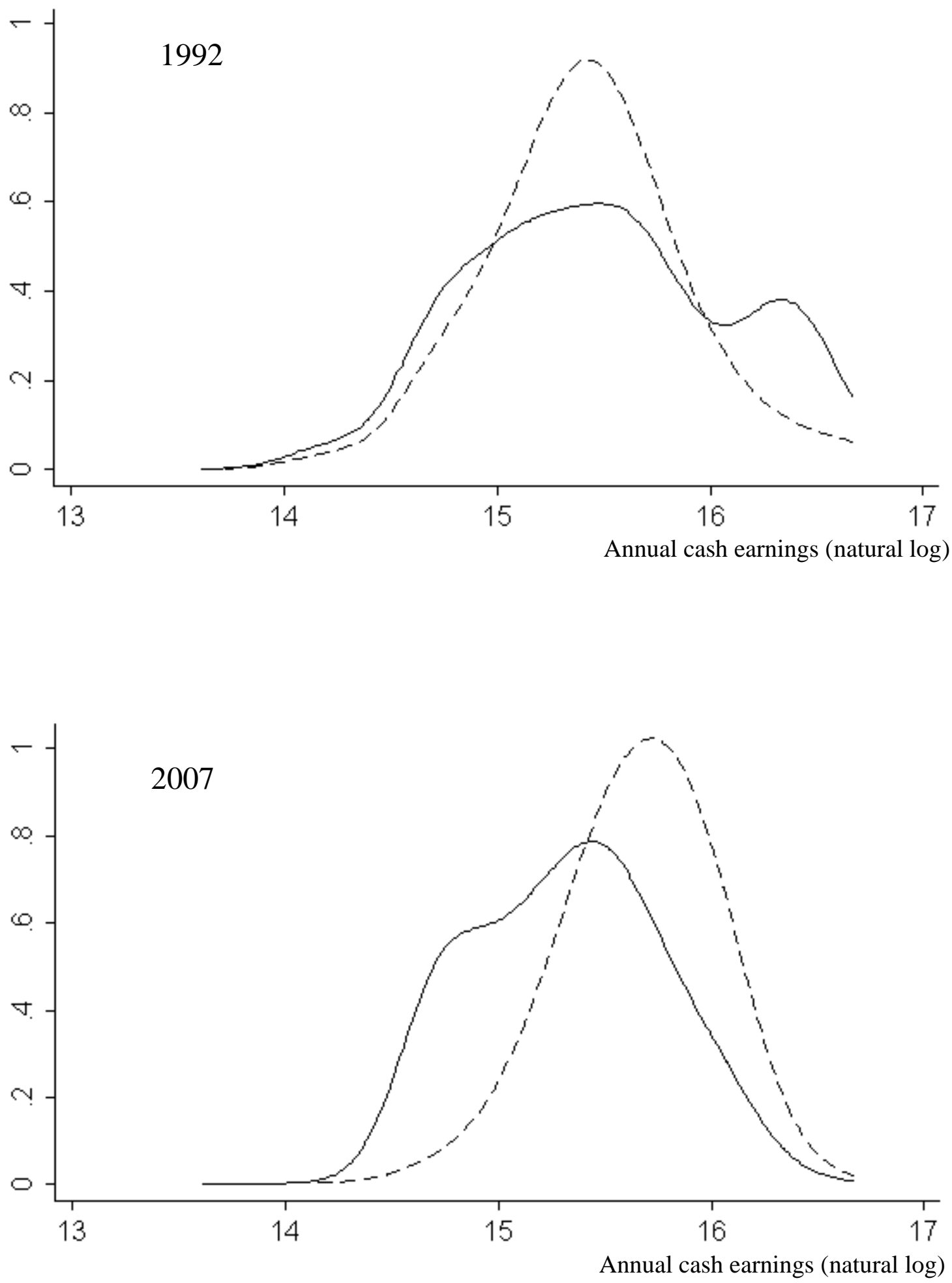

(Notes) Broken line : Actual wage distribution of union workers.

Solid line : Counterfactual wage distribution if union workers had worked as nonunion workers.

The vertical axis represents the probability density function and its integral with respect to annual cash earnings (natural log) equals 1 . The same applies to the following figures. 
Figure 2. Counterfactual kernel density, female regular workers
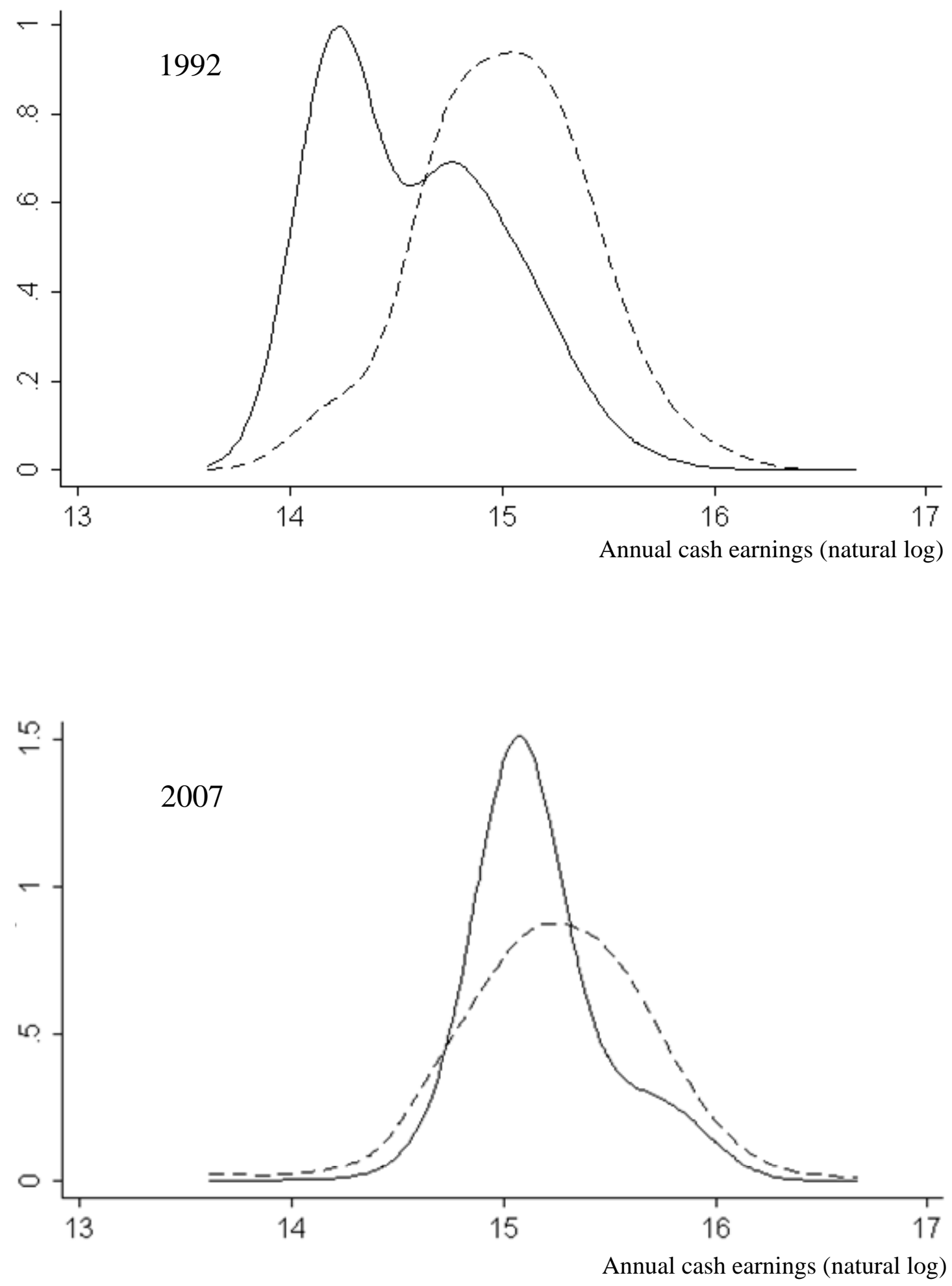

(Notes) Broken line : Actual wage distribution of union workers.

Solid line : Counterfactual wage distribution if union workers had worked as nonunion workers. 
Figure 3. Counterfactual kernel density, male regular workers
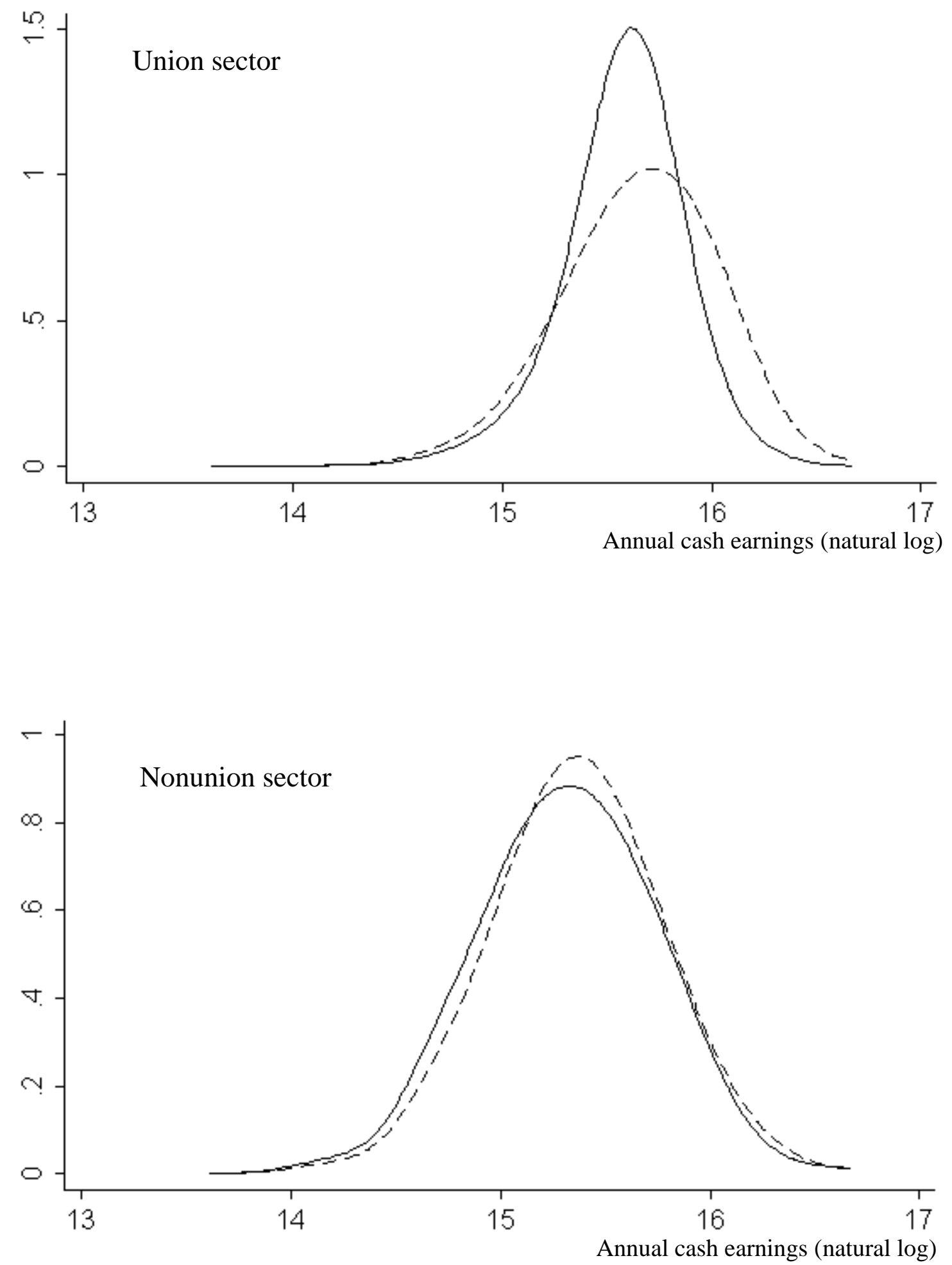

(Notes) Broken line : Actual wage distribution in 2007.

Solid line : Counterfactual wage distribution if workers in 2007 had worked in 1992. 
Figure 4. Counterfactual kernel density, female regular workers
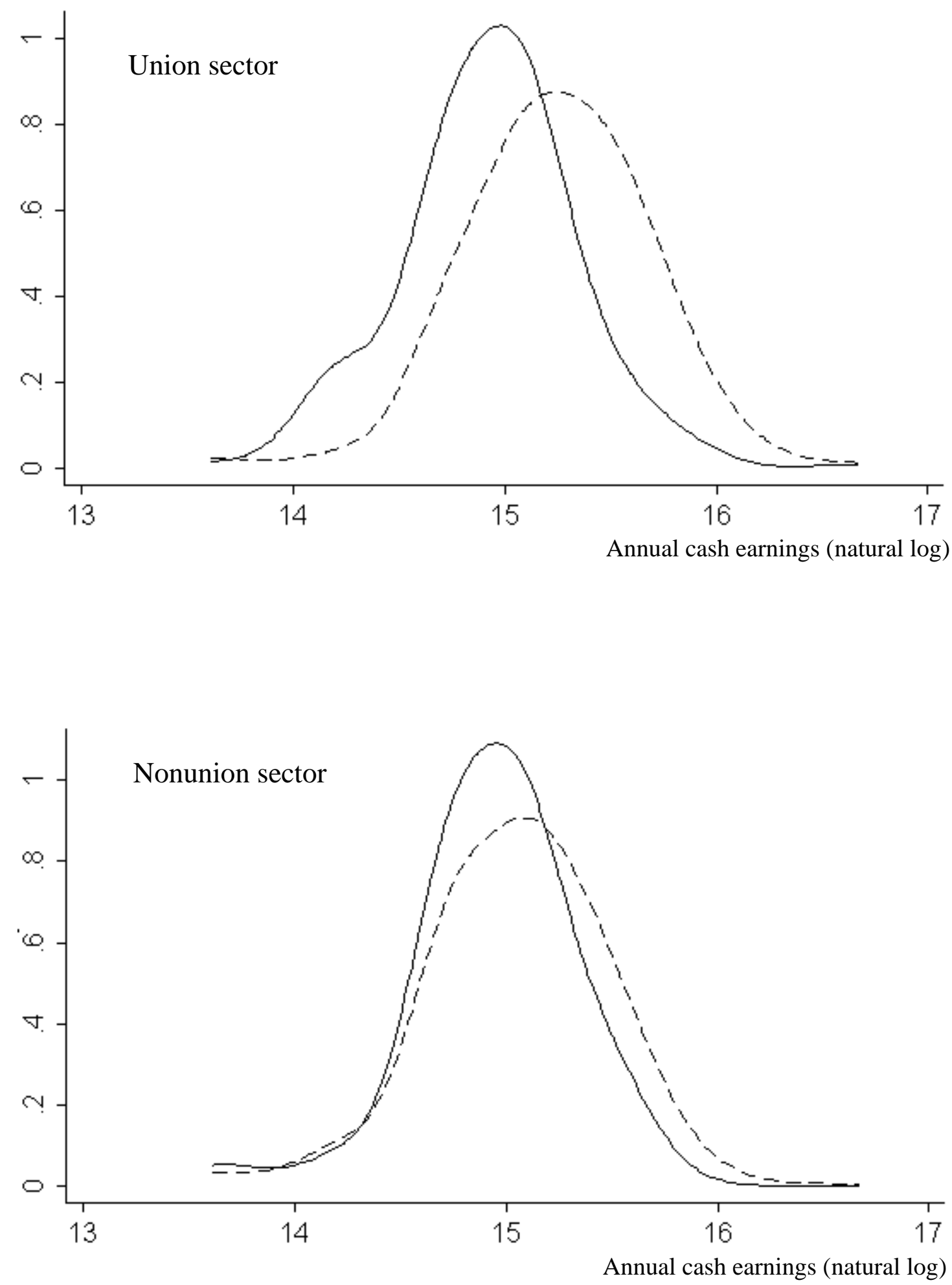

(Notes) Broken line : Actual wage distribution in 2007.

Solid line : Counterfactual wage distribution if workers in 2007 had worked in 1992. 
Figure 5. Counterfactual kernel density, male regular workers
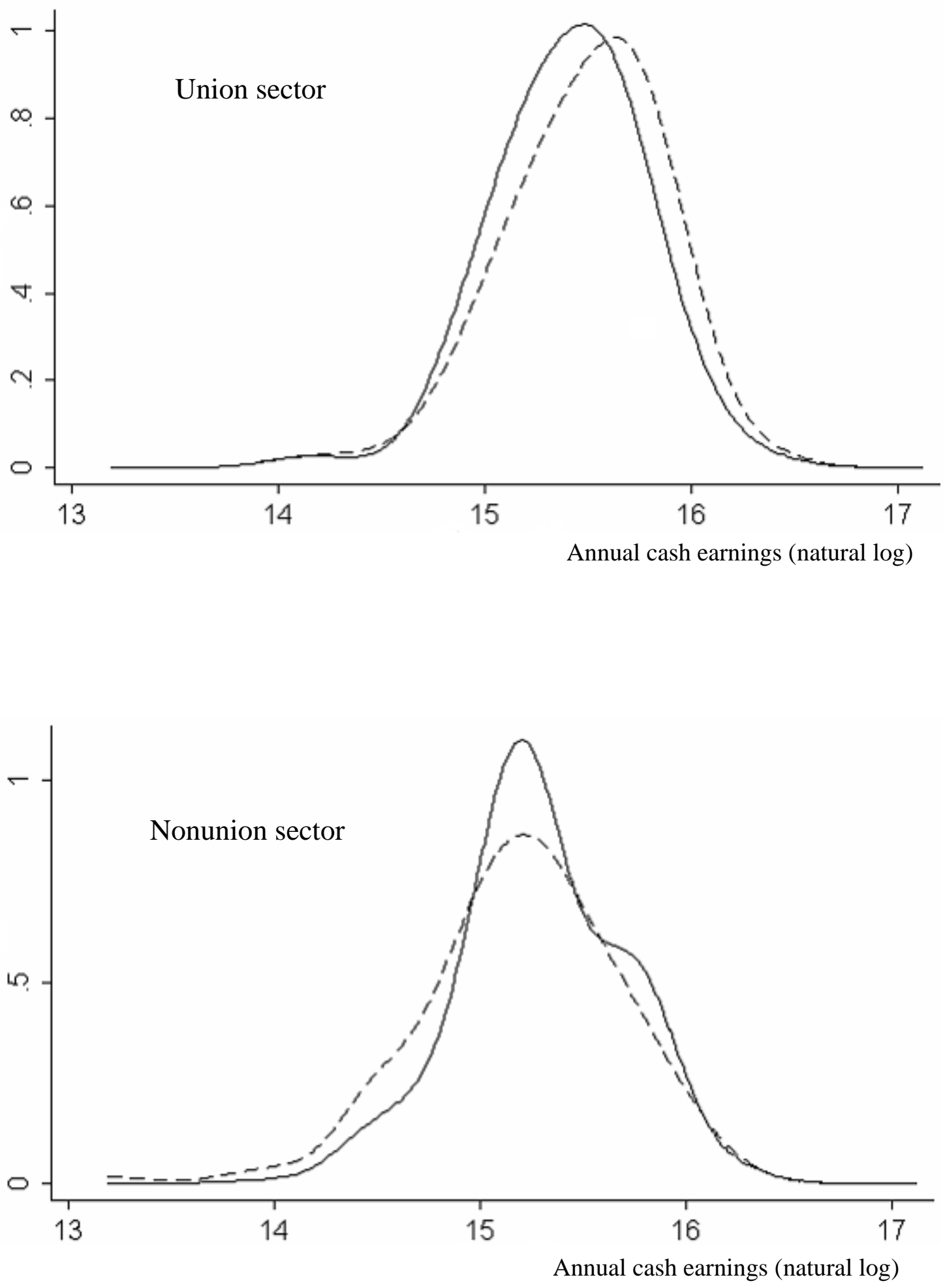

(Notes) Broken line : Actual wage distribution in 2005.

Solid line : Counterfactual wage distribution if workers in 2005 had worked in 2000. 


\section{Figure 6. Counterfactual kernel density, female regular workers}
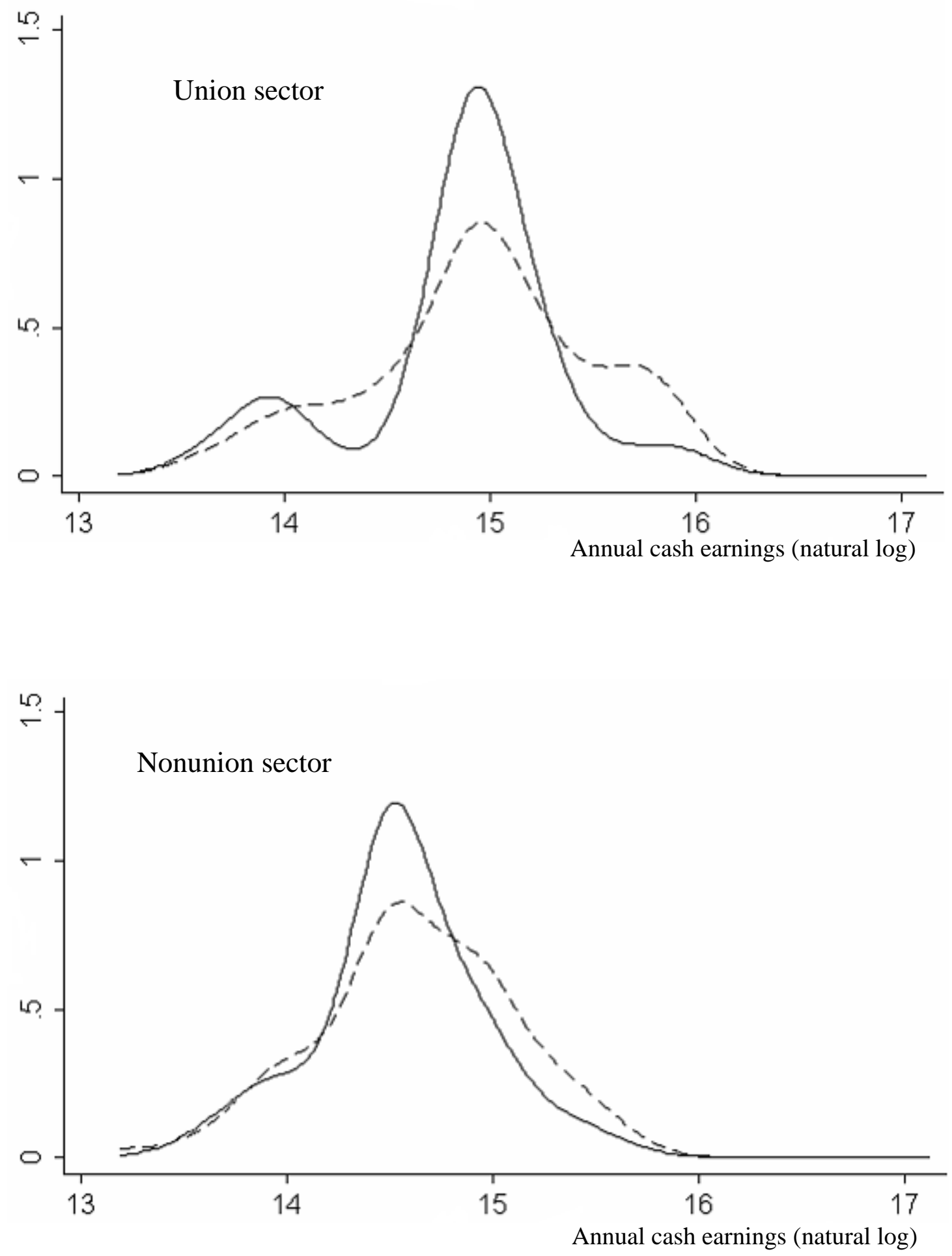

(Notes) Broken line : Actual wage distribution in 2005.

Solid line : Counterfactual wage distribution if workers in 2005 had worked in 2000. 
Table 5. Percentage of employees who would not tell anybody about problems arising at work

\begin{tabular}{|c|c|c|c|c|c|c|c|c|}
\hline \multirow{3}{*}{ Dissatisfaction with regard to } & \multicolumn{4}{|c|}{ Men } & \multicolumn{4}{|c|}{ Women } \\
\hline & \multicolumn{2}{|c|}{ Union workers } & \multicolumn{2}{|c|}{ Nonunion workers } & \multicolumn{2}{|c|}{ Union workers } & \multicolumn{2}{|c|}{ Nonunion workers } \\
\hline & 1992 & 2007 & 1992 & 2007 & 1992 & 2007 & 1992 & 2007 \\
\hline Wage level & 21.5 & 30.0 & 32.7 & 42.9 & 19.1 & 39.1 & 38.0 & 47.5 \\
\hline Welfare benefits & 25.1 & 26.6 & 40.4 & 45.9 & 17.9 & 33.7 & 45.1 & 50.1 \\
\hline Working hours, holidays, and vacation leave & 22.9 & 22.9 & 30.3 & 36.5 & 17.9 & 26.5 & 33.8 & 33.4 \\
\hline Job security & 24.2 & 24.7 & 38.8 & 43.5 & 16.7 & 32.0 & 43.9 & 44.6 \\
\hline Performance ratings & 24.7 & 28.1 & 35.9 & 43.0 & 22.6 & 35.4 & 45.1 & 46.9 \\
\hline Transfer policies & 20.2 & 24.3 & 35.9 & 40.0 & 22.6 & 27.3 & 49.0 & 40.2 \\
\hline Harassment & 32.7 & 19.5 & 43.0 & 32.3 & 15.5 & 11.7 & 37.1 & 21.8 \\
\hline
\end{tabular}

(Note) The figures in the table show the percentages of employees responding "I don't talk to anybody" to the following question: "If you have grievances at the workplace with regard to any of the following items, what would you do?" 
Table 6. Determinants of the propensity for voluntary job quitting and the degree of job dissatisfaction ${ }^{\mathrm{a}}$

\begin{tabular}{|c|c|c|c|c|c|c|c|c|}
\hline & \multicolumn{4}{|c|}{ Propensity for voluntary job quitting } & \multicolumn{4}{|c|}{ Degree of job dissatisfaction $^{c}$} \\
\hline & \multicolumn{2}{|c|}{ Men } & \multicolumn{2}{|c|}{ Women } & \multicolumn{2}{|c|}{ Men } & \multicolumn{2}{|c|}{ Women } \\
\hline & 1992 & 2007 & 1992 & 2007 & 1992 & 2007 & 1992 & 2007 \\
\hline Union member dummy & $\begin{array}{c}0.064 \\
(0.048)\end{array}$ & $\begin{array}{l}-0.093^{* * *} \\
(0.031)^{2}\end{array}$ & $\begin{array}{l}-0.016 \\
(0.076)\end{array}$ & $\begin{array}{c}0.010 \\
(0.047)\end{array}$ & $\begin{array}{c}0.183 \\
(0.131)\end{array}$ & $\begin{array}{l}-0.115 \\
(0.072)\end{array}$ & $\begin{array}{l}-0.130 \\
(0.214)\end{array}$ & $\begin{array}{c}0.012 \\
(0.100)\end{array}$ \\
\hline Annual cash earnings (natural log) & $\begin{array}{l}-0.006 \\
(0.055)\end{array}$ & $\begin{array}{l}-0.064 \\
(0.040)\end{array}$ & $\begin{array}{l}-0.045 \\
(0.077)\end{array}$ & $\begin{array}{l}-0.011 \\
(0.045)\end{array}$ & $\begin{array}{l}-0.560^{* * *} \\
(0.159)\end{array}$ & $\begin{array}{l}-0.534^{* * *} \\
(0.088)\end{array}$ & $\begin{array}{l}-0.070 \\
(0.189)\end{array}$ & $\begin{array}{l}-0.437^{* * *} \\
(0.091)\end{array}$ \\
\hline Firm size (natural log) & $\begin{array}{l}-0.012 \\
(0.010)\end{array}$ & $\begin{array}{r}-0.0003 \\
(0.007)\end{array}$ & $\begin{array}{c}0.004 \\
(0.013)\end{array}$ & $\begin{array}{l}-0.002 \\
(0.008)\end{array}$ & $\begin{array}{l}-0.064^{* *} \\
(0.028)\end{array}$ & $\begin{array}{l}-0.032^{* *} \\
(0.015)\end{array}$ & $\begin{array}{c}0.031 \\
(0.033)\end{array}$ & $\begin{array}{c}0.025 \\
(0.016)\end{array}$ \\
\hline Other independent variables ${ }^{\mathrm{d}}$ & Yes & Yes & Yes & Yes & Yes & Yes & Yes & Yes \\
\hline $\begin{array}{l}\text { No. of obs. } \\
\text { Log likelihood }\end{array}$ & $\begin{array}{c}426 \\
-162.699\end{array}$ & $\begin{array}{c}1413 \\
-713.561\end{array}$ & $\begin{array}{c}214 \\
-87.047\end{array}$ & $\begin{array}{c}851 \\
-447.715\end{array}$ & $\begin{array}{c}475 \\
-601.356\end{array}$ & $\begin{array}{c}1525 \\
-2007.813\end{array}$ & $\begin{array}{c}278 \\
-298.567\end{array}$ & $\begin{array}{c}1031 \\
-1358.218\end{array}$ \\
\hline
\end{tabular}

(Notes) ${ }^{\mathrm{a}}$ The determinants of the propensity for voluntary job quitting are estimated using a probit (marginal effects) model, while the determinants of the degree of job dissatisfaction are estimated using an ordered probit model. Standard errors are in parentheses. ${ }^{* *}$ and ${ }^{* * *}$ indicate statistical significance at the $5 \%$ and $1 \%$ level, respectively.

b The propensity for voluntary job quitting is estimated using as the dependent variable a dummy that takes a value of 1 if survey respondents answered with yes to the question whether they were thinking of changing jobs within the next 1-2 years.

c The degree of job dissatisfaction is measured based on respondents' answer to the question: "Overall, how satisfied are you with your curren working conditions?" Respondents were given the following options for their reply: 1=Extremely satisfied; 2=Quite satisfied: 3=Neither satisfied nor dissatisfied; 4=Quite dissatisfied; 5=Extremely dissatisfied.

${ }^{\mathrm{d}}$ Other independent variables included in the estimations are the explanatory variables used in the estimation of the wage function in Table 4 as well as occupation and industry dummies. 
Table 7. Attitudes toward unionization

\begin{tabular}{rr|c}
\hline & Support unionization & $\begin{array}{c}\text { Do not support } \\
\text { unionization }\end{array}$ \\
\hline 1992 & 43.3 & 56.7 \\
Men & 37.8 & 62.2 \\
Women & 40.7 & 59.3 \\
\hline Total & & \\
Men & $55.7^{* * *}$ & $44.3^{* * *}$ \\
Women & 43.1 & 56.9 \\
Total & 50.1 & 49.9 \\
\hline
\end{tabular}

(Note) ${ }^{* * *}$ indicates that there is a statistically significant difference in the means for men and women at the $1 \%$ level. 
Table 8. Support for unionization among nonunion workers in the private sector (Marginal effect)

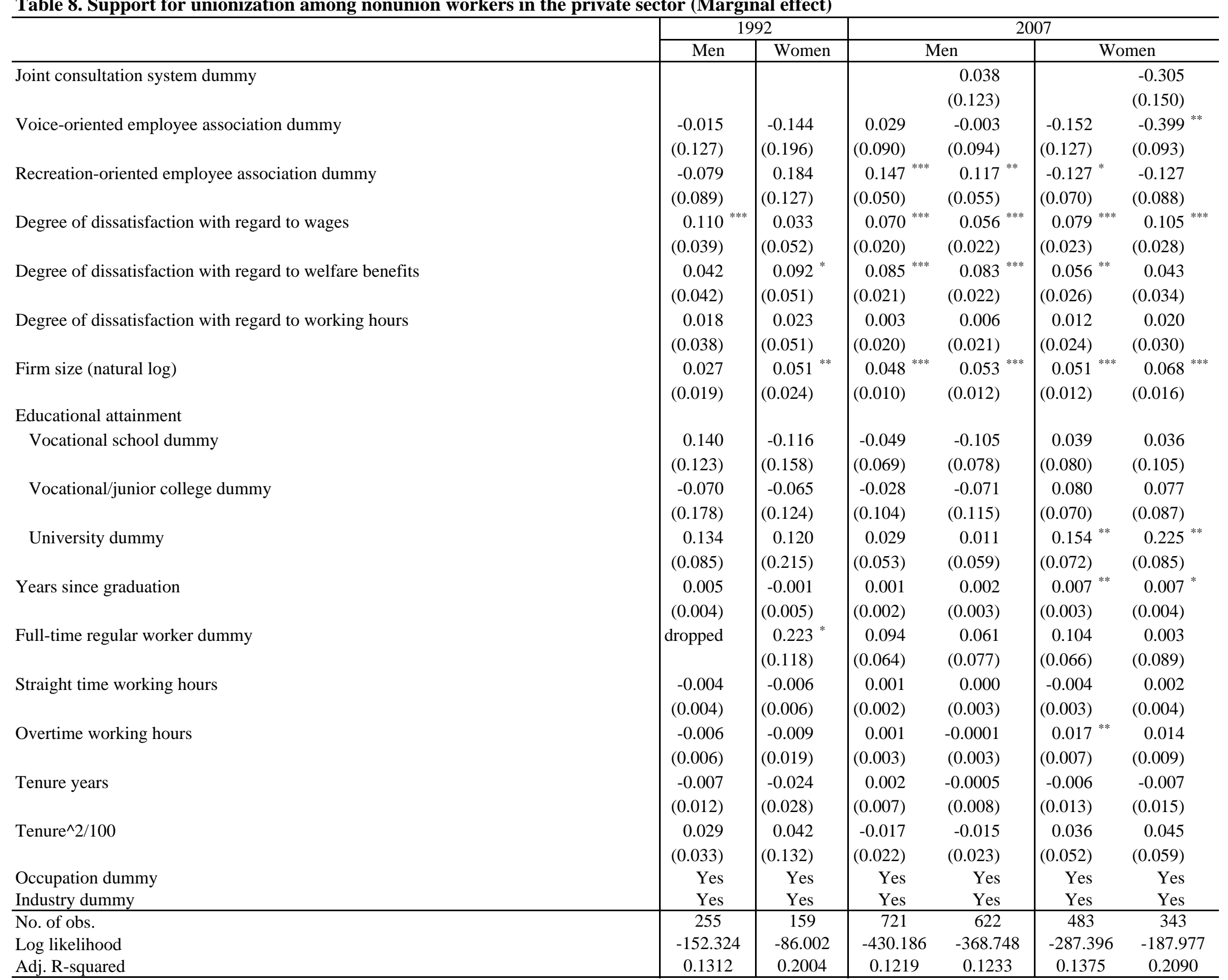

(Notes) Estimated using probit estimation. The dependent variable is a dummy for supporting unionization (support $=1$ ).

Standard errors are given in parentheses. ${ }^{* * *},{ }^{* *}$ and ${ }^{*}$ indicate statistical significance at the $1 \%, 5 \%$, and $10 \%$ level, respectively. 
Figure 7.Wage differentials between men and women by firm size
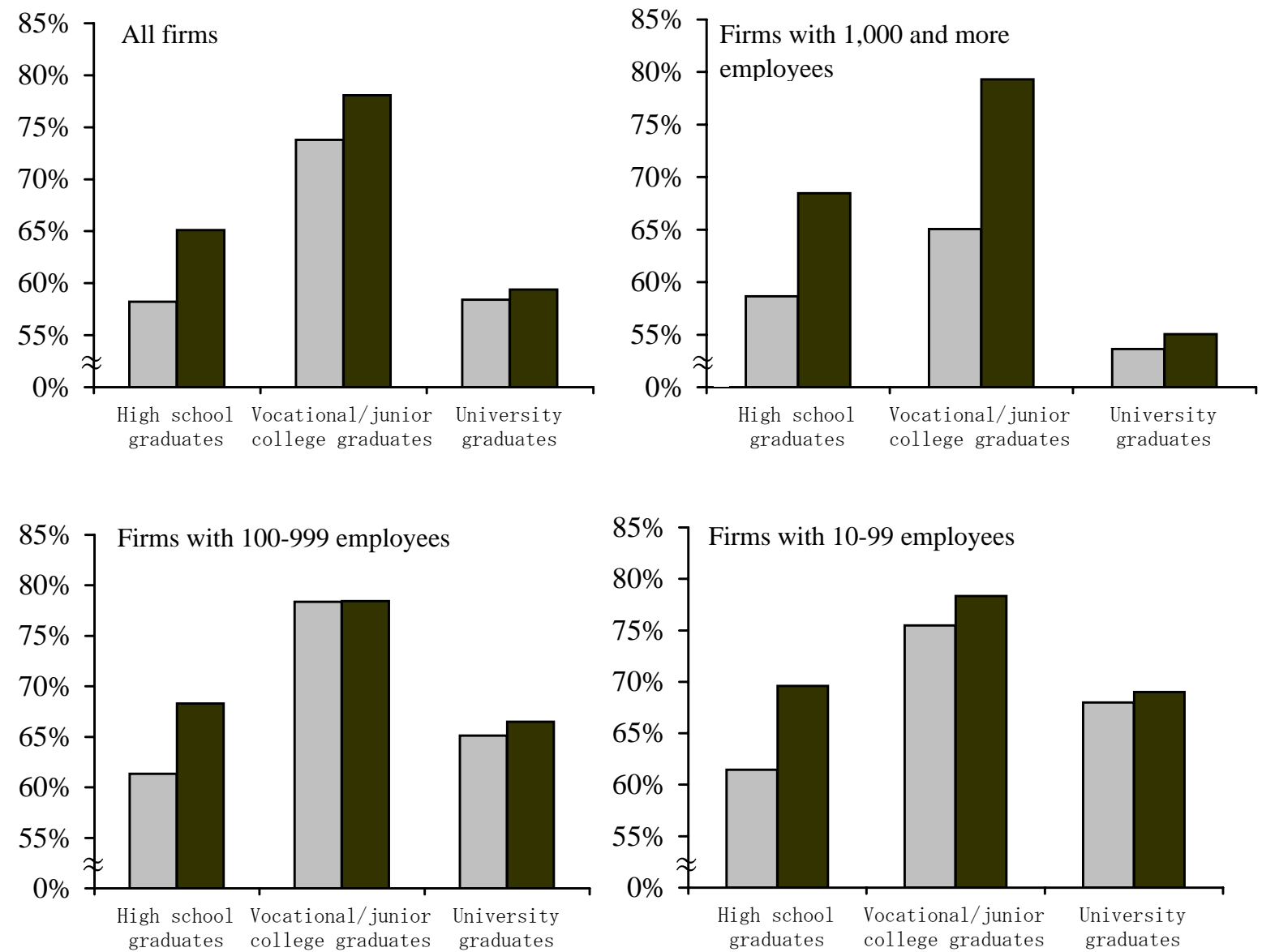

(Notes) ${ }^{a}$ Based on data from the "Basic Survey on Wage Structure" (1992 and 2007) published by the Ministry of Health, Labour and Welfare. The survey for 2007 covers approximately 78,000 establishments and about 1.61 million workers.

b The figure shows the ratio of female standard workers' wages to male standard workers' wages for all ages by firm size and academic achievement.

${ }^{c}$ The wage data were obtained by adding annual bonuses and other special cash earnings to the annualized amount of scheduled cash earnings.

${ }^{\mathrm{d}}$ Values are for industries in total.

e The comparison here is for "standard workers," defined as those that directly entered a firm after graduation and then worked for the same firm continously. 
Figure 8. Percentage of firms seeing "personnel retrenchment and natural attrition" as the most important measures to reduce personnel costs

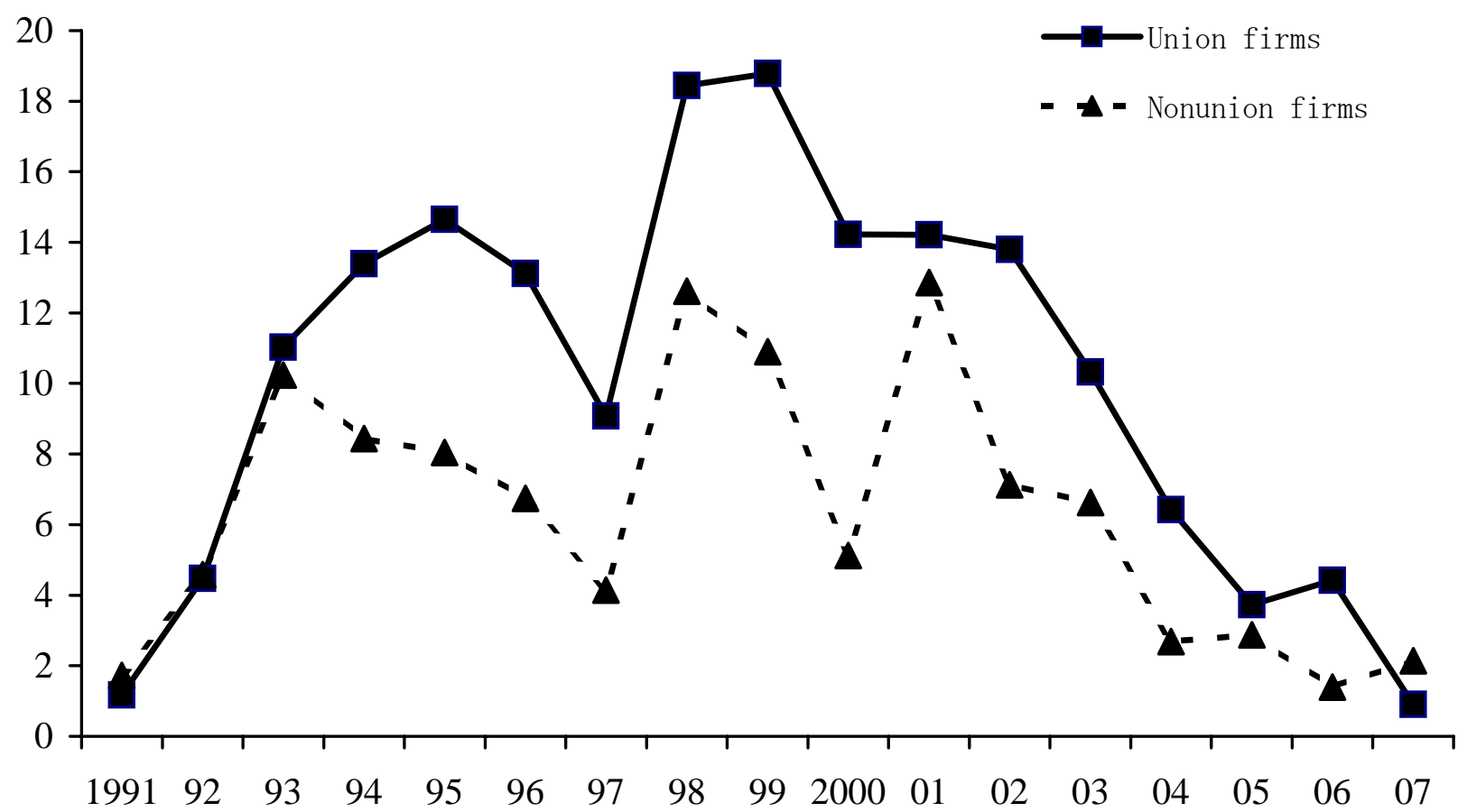

(Source) Tsuru et al.(2009).

(Notes) ${ }^{\text {a }}$ Based on an analysis of microdata of the Ministry of Health, Labour and Welfare's Survey on Wage Increases (1991-2007).

b Based on firms with 100 or more employees. Figures were also aggregated by firm size, but the pattern was generally the same. 
Table 9. Regular pay raises, by type of firm (share in \%)

\begin{tabular}{|c|c|c|c|c|c|c|c|c|c|c|}
\hline & \multicolumn{5}{|c|}{ Union firms } & \multicolumn{5}{|c|}{ Nonunion firms } \\
\hline & \multirow{2}{*}{$\begin{array}{l}\text { No system } \\
\text { of regular } \\
\text { pay raises }\end{array}$} & \multirow{2}{*}{$\begin{array}{l}\text { System of } \\
\text { regular } \\
\text { nav raises }\end{array}$} & & & & \multirow{2}{*}{\begin{tabular}{|l|} 
No system \\
of regular \\
pay raises
\end{tabular}} & \multirow{2}{*}{$\begin{array}{l}\text { System of } \\
\text { regular } \\
\text { pay raises }\end{array}$} & \multirow[b]{2}{*}{$\begin{array}{l}\text { Implemted/ } \\
\text { implementing }\end{array}$} & \multirow[b]{2}{*}{$\begin{array}{l}\text { Not implemted/ } \\
\text { implementing }\end{array}$} & \multirow[b]{2}{*}{ Postponed } \\
\hline & & & $\begin{array}{l}\text { Implemted/ } \\
\text { implementing }\end{array}$ & $\begin{array}{l}\text { Not implemted/ } \\
\text { implementing }\end{array}$ & Postponed & & & & & \\
\hline 2003 & 29.9 & 70.1 & 62.7 & 6.9 & 0.5 & 32.9 & 67.1 & 48.5 & 18.4 & 0.2 \\
\hline 2004 & 27.4 & 72.6 & 64.5 & 7.8 & 0.4 & 36.2 & 63.8 & 54.1 & 9.3 & 0.4 \\
\hline 2005 & 29.6 & 70.4 & 66.3 & 4.1 & 0.0 & 33.2 & 66.8 & 53.8 & 11.9 & 1.2 \\
\hline 2006 & 25.6 & 74.4 & 69.8 & 4.6 & 0.1 & 28.3 & 71.7 & 61.7 & 9.6 & 0.4 \\
\hline 2007 & 26.4 & 73.6 & 68.6 & 4.9 & 0.1 & 26.4 & 73.6 & 65.4 & 8.1 & 0.1 \\
\hline
\end{tabular}

(Source) Tsuru et al.(2009).

(Notes) ${ }^{a}$ Based on an analysis of microdata of the Ministry of Health, Labour and Welfare's Survey on Wage Increases (2003-2007).

${ }^{\mathrm{b}}$ Based on firms with 100 or more employees. Figures were also aggregated by firm size, but the pattern was generally the same. 